\title{
National Register Testing at 41SV153, Somervell County, Texas
}

Timothy B. Griffith

Douglas K. Boyd

Follow this and additional works at: https://scholarworks.sfasu.edu/ita

Part of the American Material Culture Commons, Archaeological Anthropology Commons, Environmental Studies Commons, Other American Studies Commons, Other Arts and Humanities Commons, Other History of Art, Architecture, and Archaeology Commons, and the United States History Commons

Tell us how this article helped you.

This Article is brought to you for free and open access by the Center for Regional Heritage Research at SFA ScholarWorks. It has been accepted for inclusion in Index of Texas Archaeology: Open Access Gray Literature from the Lone Star State by an authorized editor of SFA ScholarWorks. For more information, please contact cdsscholarworks@sfasu.edu. 


\section{National Register Testing at 41SV153, Somervell County, Texas}

\section{Licensing Statement}

This is a work for hire produced for the Texas Department of Transportation (TxDOT), which owns all rights, title, and interest in and to all data and other information developed for this project under its contract with the report producer. The report may be cited and brief passages from this publication may be reproduced without permission provided that credit is given to TxDOT and the firm that produced it. Permission to reprint an entire chapter, section, figures or tables must be obtained in advance from the Supervisor of the Archeological Studies Branch, Environmental Affairs Division, Texas Department of Transportation, 125 East 11th Street, Austin, Texas, 78701. 


\title{
NATIONAL REGISTER TESTING AT 41SV153, SOMERVELL COUNTY, TEXAS
}

\author{
by \\ Timothy B. Griffith \\ and \\ Douglas K. Boyd \\ Principal Investigator: Ross C. Fields \\ TECHNICAL REPORTS, NUMBER 75 \\ Prewitt and Associates, Inc. \\ Cultural Resources Services \\ Austin, Texas
}

ARCHEOLOGICAL STUDIES PROGRAM, REPORT NO. 88

Texas Department of Transportation

Environmental Affairs Division

CSJ No. 0385-05-021

March 2006

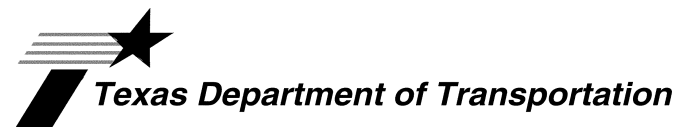

TEXAS ANTIQUITIES PERMIT NO. 3660 


\section{NATIONAL REGISTER TESTING AT 41SV153, SOMERVELL COUNTY, TEXAS}

Copyright @ 2006

Texas Department of Transportation (TxDOT) and Prewitt and Associates, Inc. (PAI)

TxDOT and PAI jointly own all rights, title, and interest in and to all data and other information developed for this project under Contract 575XXSA006. Brief passages from this publication may be reproduced without permission provided that credit is given to TxDOT and PAI. Permission to reprint an entire chapter, section, figures or tables must be obtained in advance from the Supervisor of the Archeological Studies

Program, Environmental Affairs Division, Texas Department of Transportation, 125 East 11th Street, Austin, Texas, 78701. Copies of this publication have been deposited with the Texas State Library in compliance with the State Depository Requirement.

jointly published by the

Texas Department of Transportation

Environmental Affairs Division

Archeological Studies Program

G. Lain Ellis, Ph.D., Supervisor

Archeological Studies Program, Report No. 88

CSJ No. 0385-05-021

Al McGraw, Series Editor

and

Prewitt and Associates, Inc.

Cultural Resources Services

Austin, Texas

Technical Reports, Number 75

Printed by Morgan Printing in Austin, Texas

ISBN 1-930788-58-4 


\section{TABLE OF CONTENTS}

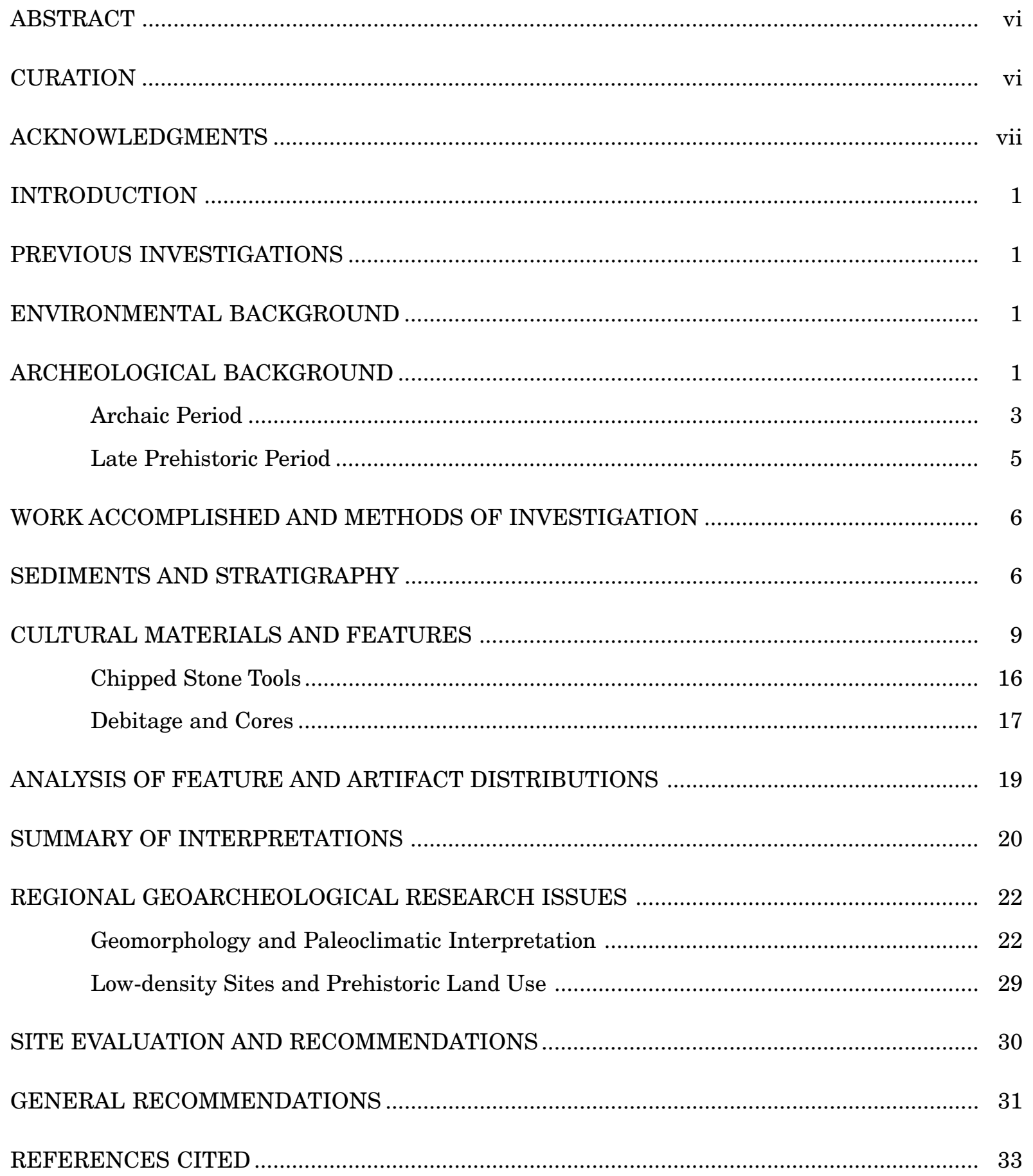




\section{FIGURES}

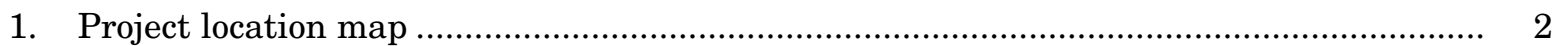

2. Photograph of 41SV153 on the first terrace of Squaw Creek ............................................ 3

3. Map of project area showing location of backhoe trenches and test units ......................... 8

4. Profile drawing of stratigraphic zones in the western half of Backhoe Trench 8 ............. 10

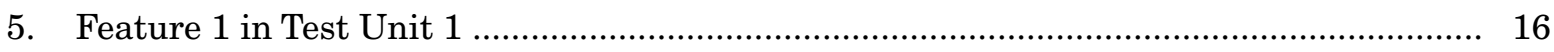

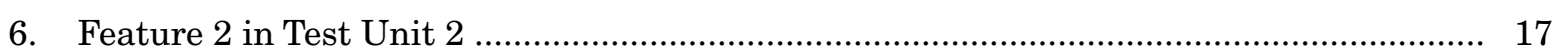

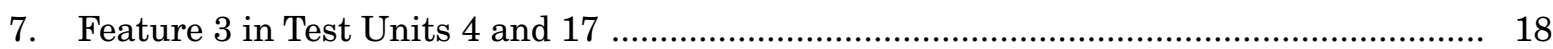

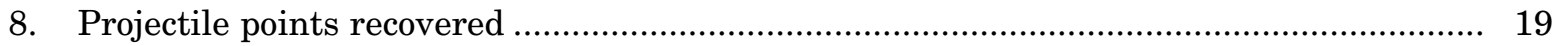

9. Comparison of densities of burned rocks and chipped stone artifacts by test unit ........... 21

10. Photograph of alluvial sediments exposed in Backhoe Trench 8 ................................... 23

11. Geology of the lower Squaw Creek valley in the general vicinity of 41SV153 ................. 24

12. Topography of the lower Squaw Creek valley in the general vicinity of 41SV153 ............ 25

13. Map of the Brazos River valley in north-central Texas showing selected

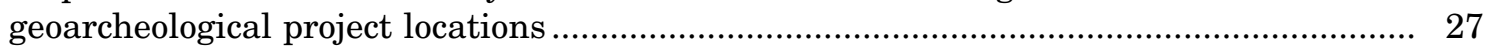




\section{TABLES}

1. Summary of excavated test units and artifact recovery ............................................... 7

2. Provenience of cultural materials recovered from flotation samples .............................. 9

3. Detailed provenience of cultural materials recovered .................................................. 11

4. Densities of burned rocks and artifacts by test unit .................................................... 20

5. Comparison of archeological data for 41SV4 and 41SV153 .......................................... 30 


\begin{abstract}
Archeological test excavations at 41SV153 were completed by Prewitt and Associates, Inc., in 2004 in conjunction with Texas Department of Transportation road improvements on State Highway 144 in eastern Somervell County. The site is situated in Holocene alluvial deposits adjacent to Squaw Creek, a tributary of the Brazos River. Excavations revealed sparse lithic artifacts, scattered burned rocks, and displaced burned rock features. No organic remains were recovered, and the age of the cultural occupations is not known. The portion of 41SV153 within the proposed construction easement is considered not eligible for listing in the National Register of Historic Places or designation as a State Archeological Landmark. A prominent geological unconformity in the alluvial stratigraphy probably represents an early to middle Holocene erosional event and has implications for paleoclimatic and archeological studies in north-central Texas.
\end{abstract}

\title{
CURATION
}

The artifacts recovered during this project were given to the State of Texas by the landowner through Deed of Gift. All project records and collected artifacts from this project will be submitted to the Texas Archeological Research Laboratory (J. J. Pickle Research Campus, The University of Texas at Austin) for permanent curation on behalf of the Texas Department of Transportation. 


\section{ACKNOWLEDGMENTS}

This project was successful through the assistance of several persons. Timothy B. Griffith served as project archeologist with the guidance of Doug Boyd (project manager) and Ross Fields (principal investigator). Much appreciation is extended to the field crew for their great effort. Project crew members were Rob Thrift, Greg LaBudde, Mark Holderby, and Weldon Hammond. Mr. Thrift also performed the site mapping with an electronic total station.

Other persons who aided in completing this project include TxDOT personnel. For the Fort Worth District office, Sonja Whitehead coordinated our work and scheduled the backhoe and operator. Dennis Price and the staff of TxDOT's Archeological Studies Program (Environmental Affairs Division, Austin) also provided assistance with comments and directions on all phases of this project.

The staff at Prewitt and Associates, Inc., also lent their expertise in report editing and advice throughout all phases of the project. Artifacts were washed and processed in the laboratory by Jonathan S. Grant. Brian J. Wootan and Sandy Hannum produced the maps, photos, and illustrations in the report. Jane Sevier edited and produced this report. 



\section{INTRODUCTION}

Archeological testing of 41SV153 was conducted by Prewitt and Associates, Inc. (PAI), for the Texas Department of Transportation (TxDOT) Environmental Affairs Division under Contract No. 575XXSA006 (Work Authorization No. 57507SA006) and Texas Antiquities Permit No. 3660 from the Texas Historical Commission. Fieldwork was initiated on March 8, 2004, and concluded March 11, 2004. Laboratory processing and interim report preparation took place during March 2004. The work was done to assist TxDOT in complying with Section 106 of the National Historic Preservation Act and the Antiquities Code of Texas. A portion of the site extends into temporary easement needed for the proposed replacement of the State Highway 144 bridge over Squaw Creek in Somervell County. Archeological investigations were restricted to the part of the site within the easement.

Site 41SV153 is in central Somervell County approximately $2.5 \mathrm{~km}$ north of Glen Rose, Texas (Figure 1). The site is situated at a maximum elevation of ca. $620 \mathrm{ft}$ above sea level on an alluvial flood terrace along the north bank of Squaw Creek adjoining the channel. The floodplain containing the site is a well-manicured, open pasture. The project area is mapped as Holocene alluvial terrace deposits (Bureau of Economic Geology 1988). The project was prompted by TxDOT's proposed plan to replace the State Highway 144 bridge over Squaw Creek, which, with the acquisition of a temporary construction easement east of the highway, will directly affect $41 \mathrm{SV} 153$. As described below, 41SV153 is a buried prehistoric site contained in Holocene alluvium. Archeological testing consisted of excavating six backhoe trenches, as well as hand excavation of fifteen $50 \times 50-\mathrm{cm}$ and two $1 \times 1-\mathrm{m}$ units. This work resulted in the recovery of a small artifact collection and identification of three cultural features.

\section{PREVIOUS INVESTIGATIONS}

Personnel from PAI recorded 41SV153 in 2004 during an intensive survey for TxDOT's proposed State Highway 144 bridge replacement over Squaw Creek (Gibbs 2004). Cultural materials were recorded in two of the three trenches excavated across the floodplain that contains the site. The site was recorded as a dense lens of burned rocks and scattered chert flakes found between 30 and $80 \mathrm{~cm}$ below the ground surface. Dense accumulations of burned rocks were noted, and most of the cultural materials were observed in the trench walls. The initial survey was unable to determine the site's eligibility for listing in the National Register of Historic Places or designation as a State Archeological Landmark, therefore, testing was recommended.

\section{ENVIRONMENTAL BACKGROUND}

Somervell County is in north-central Texas at the eastern edge of the Western Cross Timbers environmental region. The flora of the Western Cross Timbers consists of primarily post oak and blackjack oak deciduous woodlands (Diamond et al. 1987). Most of Somervell County is drained by the Brazos River. Squaw Creek is a tributary to the Paluxy River, converging with it at the point where the Paluxy flows into the Brazos River. Site 41 SV153 is situated ca. 6$7 \mathrm{~m}$ above the Squaw Creek channel on the broad, level first terrace (Figure 2).

As described in the soil survey for Hood and Somervell counties (Coburn 1978:1), the climate of Somervell County is classified as hot summers and cool winters. During the winter months, an occasional surge of cold air can drop temperatures significantly. These cold spells are brief, and winter temperatures typically are mild. Mean daily maximum and minimum temperatures for winter are $48^{\circ} \mathrm{F}$ and $35^{\circ} \mathrm{F}$; mean daily temperatures for summer are $96^{\circ} \mathrm{F}$ and $84^{\circ} \mathrm{F}$ (Coburn 1978). The average annual rainfall is 30.56 inches. Sixty percent, 18 inches, of the annual precipitation usually falls in April through September. Prevailing winds are from the south.

\section{ARCHEOLOGICAL BACKGROUND}

The Squaw Creek area in Somervell County is considered part of the central Texas archeological region because of its location on the northern margins of the Edwards Plateau, although the region is close to the north-central Texas archeological region as well. The prehistoric cultural sequence in the central Texas archeological region is based on decades of 


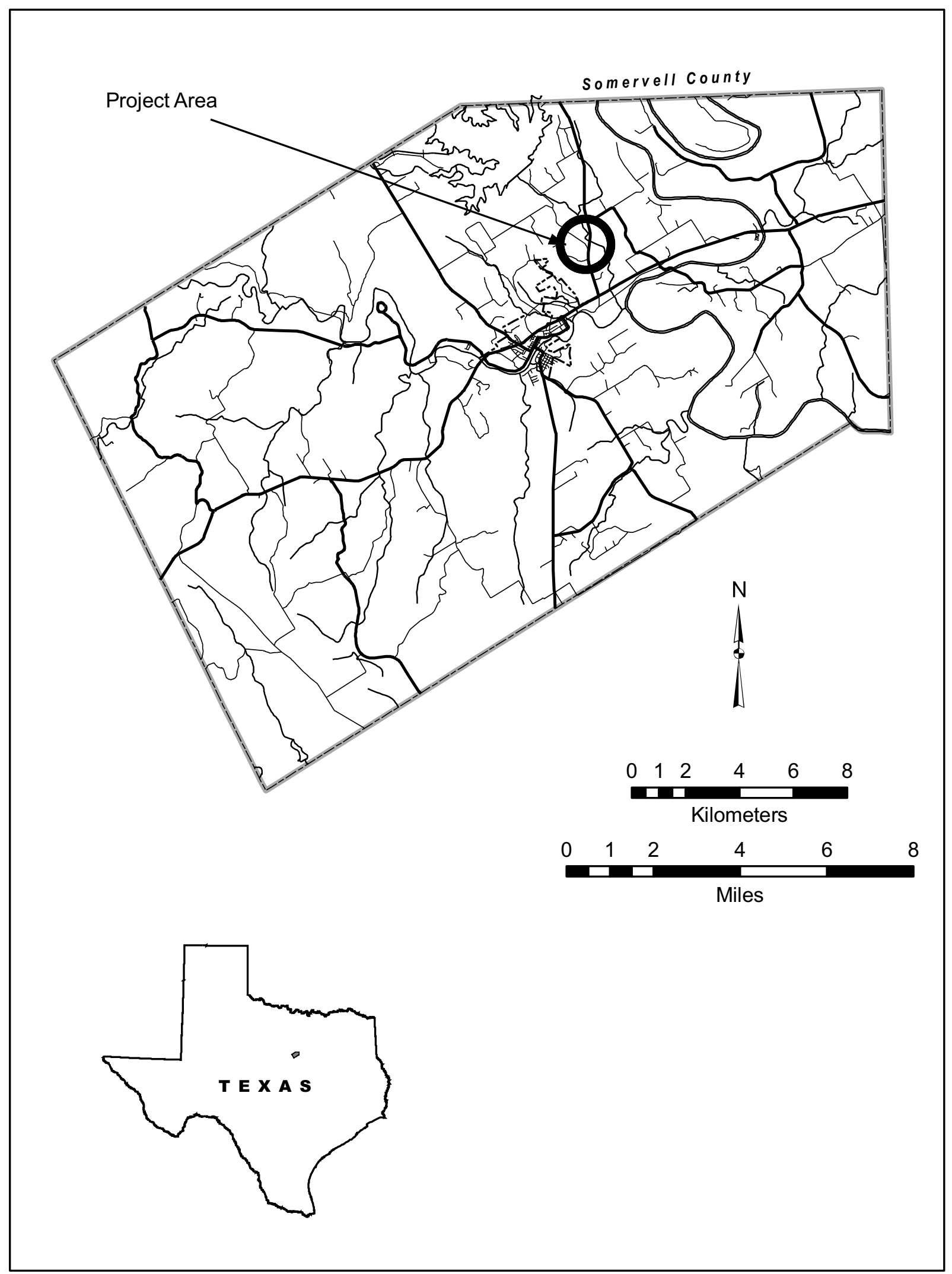

Figure 1. Project location map. 


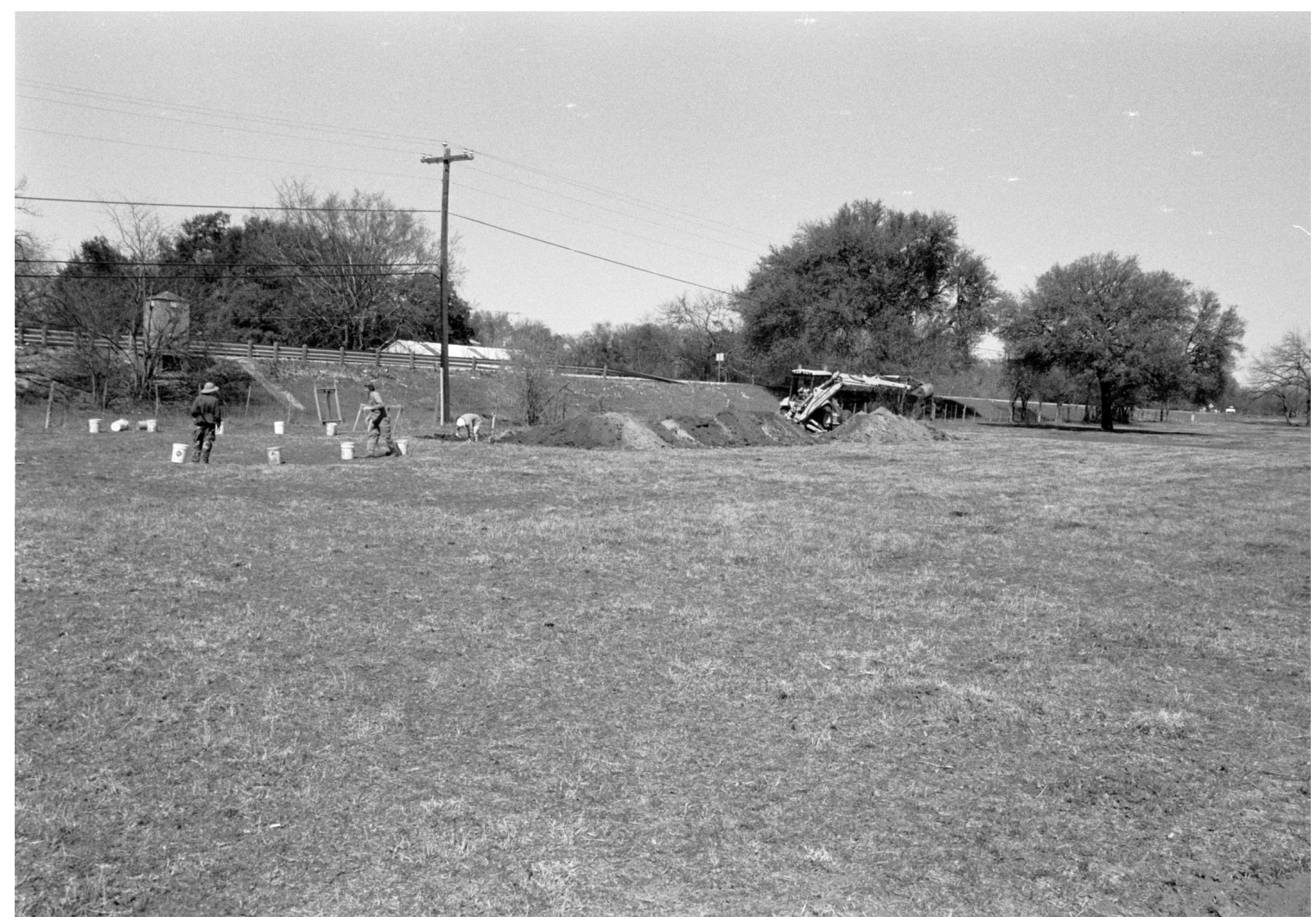

Figure 2. Photograph of 41SV153 on the first terrace of Squaw Creek. View is to the northwest with State Highway 144 behind the site.

investigations at various stratified sites and burned rock middens throughout the Edwards Plateau. Because the cultural deposits at 41SV153 date to the late Holocene, this cultural background begins with the Archaic period.

\section{Archaic Period}

The Archaic period for central Texas dates from ca. 8800 to $1300-1200$ B.P. (Collins 1995) and generally is believed to represent an economy based on hunting and gathering of a wide array of animal and plant resources and limited group mobility (Willey and Phillips 1958:107-108). In the eastern and southwestern United States and on the Great Plains, development of horticultural-based, semisedentary to sedentary societies succeeded the Archaic period. In these areas, the Archaic truly represents a developmental stage of adaptation as Willey and Phillips (1958) define it. For central Texas, this notion of the Archaic is somewhat problematic. An increasing amount of evidence suggests that Archaic-like adaptations were in place before the Archaic (see Collins 1995:381-382, 1998; Collins et al. 1989) and that these practices continued into the succeeding Late Prehistoric period (Collins 1995:385; Prewitt 1981:74). In a real sense, the Archaic period of central Texas is not a developmental stage, but an arbitrary chronological construct and projectile point style sequence. Establishment of this sequence is based on several decades of archeological investigations at stratified Archaic sites along the eastern and southern margins of the Edwards Plateau. Collins (1995) and Johnson and Goode (1994) have divided this sequence into three parts-early, middle, and late-based on perceived (though not fully agreed on by all scholars) technological, environmental, and adaptive changes.

Early Archaic (8800-6000 B.P.) sites are small, and their tool assemblages are diverse (Weir 1976:115-122), suggesting that populations were highly mobile and overall population densities were low (Prewitt 1985:217). It has been noted that Early Archaic sites are concentrated along the eastern and southern margins 
of the Edwards Plateau (Johnson and Goode 1994; McKinney 1981). This distribution may indicate relatively dry climatic conditions at the time, given that these environments have morereliable water sources and a more-diverse resource base than other parts of the region. Early Archaic projectile point styles include Hoxie, Gower, Wells, Martindale, and Uvalde. Clear Fork and Guadalupe bifaces and a variety of other bifacial and unifacial tools are common to Early Archaic assemblages. Construction and use of rock hearths and ovens, which had been limited during late Paleoindian times, became commonplace. The use of rock features suggests that retaining heat and releasing it slowly over an extended period were important in food processing and cooking and reflects a specialized subsistence strategy. Such a practice probably was related to cooking plant foods, particularly roots and bulbs, many of which must be subjected to prolonged periods of cooking to render them consumable and digestible (Black et al. 1997:257; Wandsnider 1997; Wilson 1930). Botanical remains, as well as other organic materials, are often poorly preserved in Early Archaic sites, so the range of plant foods exploited and their level of importance in the overall subsistence strategy are scantily understood. But recovery of charred wild hyacinth (Camassia scilloides) bulbs from an Early Archaic feature at the Wilson-Leonard site provides some insights into the types of plant foods used and their importance in the Early Archaic diet (Collins et al. 1998). Significant Early Archaic sites include the Richard Beene site in Bexar County (Thoms and Mandel 1992), the Camp Pearl Wheat site in Kerr County (Collins et al. 1990), and the Jetta Court site in Travis County (Wesolowsky et al. 1976).

During the Middle Archaic period (6000 4000 B.P.), the number and distribution of sites, as well as their size, probably increased as population densities grew (Prewitt 1981:73; Weir 1976:124, 135). Macrobands may have formed at least seasonally, or more small groups may have used the same sites for longer periods (Weir 1976:130-131). Development of burned rock middens toward the end of the Middle Archaic suggests a greater reliance on plant foods, although tool kits still imply a considerable dependence on hunting (Prewitt 1985:222-226). Middle Archaic projectile point styles include
Bell, Andice, Taylor, Baird, Nolan, and Travis. Bell and Andice points reflect a shift in lithic technology from the preceding Early Archaic Martindale and Uvalde point styles (Collins 1995:384). Johnson and Goode (1994:25) suggest that the Bell and Andice darts were parts of a specialized bison-hunting tool kit. They also believe that an influx of bison and bisonhunting groups from the Eastern Woodland margins during a slightly more mesic period marked the beginning of the Middle Archaic. Though no bison remains were recovered or present, Bell and Andice points and associated radiocarbon ages were recovered from the Cibolo Crossing (Kibler and Scott 2000), Panther Springs Creek, and Granberg II (Black and McGraw 1985) sites in Bexar County. Bison became scarce as more-xeric conditions returned during the late part of the Middle Archaic. Later Middle Archaic projectile point styles represent another shift in lithic technology (Collins 1995:384; Johnson and Goode 1994:27). Prewitt (personal communication 2000) postulates that the production and morphology of Travis and Nolan points are similar to projectile points from the Lower Pecos region. Because they appeared earlier in the Lower Pecos than in central Texas, such characteristics as beveled stems and overall morphology may have originated in the Lower Pecos. At the same time, a shift to morexeric conditions saw the burned rock middens develop, probably because intensified use of a specific resource (geophytic or xerophytic plants) or resource patches meant the debris of multiple rock ovens and hearths accumulated as middens on stable to slowly aggrading surfaces, as Kelley and Campbell (1942) suggested many years ago. Johnson and Goode (1994:26) believe that the dry conditions promoted the spread of yuccas and sotols, and that it was these plants that Middle Archaic peoples collected and cooked in large rock ovens.

During the succeeding Late Archaic period (4000 to 1300-1200 B.P.), populations continued to increase (Prewitt 1985:217). Within stratified Archaic sites such as Loeve-Fox, Cibolo Crossing, and Panther Springs Creek, the Late Archaic components contain the densest concentrations of cultural materials. Establishment of large cemeteries along drainages suggests certain groups had strong territorial ties (Story 1985:40). A variety of projectile point styles appeared throughout the Late Archaic period. 
Johnson and Goode (1994:29-35) divide the Late Archaic into two parts, Late Archaic I and II, based on increased population densities and perceived evidence of Eastern Woodland ceremonial rituals and religious ideological influences. Middle Archaic subsistence technology, including the use of rock and earth ovens, continued into the Late Archaic period. Collins (1995:384) states that, at the beginning of the Late Archaic period, the use of rock ovens and the resultant formation of burned rock middens reached its zenith and that the use of rock and earth ovens declined during the latter half of the Late Archaic. There is, however, mounting chronological data that midden formation culminated much later and that this high level of rock and earth oven use continued into the early Late Prehistoric period (Black et al. 1997:270-284; Kleinbach et al. 1995:795). A picture of prevalent burned rock midden development in the eastern part of the central Texas region after 2000 B.P. is gradually becoming clear. This scenario parallels the widely recognized occurrence of post-2000 B.P. middens in the western reaches of the Edwards Plateau (see Goode 1991).

The use of rock and earth ovens (and the formation of burned rock middens) for processing and cooking plant foods suggests that this technology was part of a generalized foraging strategy. The amount of energy involved in collecting plants, constructing hot rock cooking appliances, and gathering fuel ranks most plant foods relatively low based on the resulting caloric return (Dering 1999). This suggests that plant foods were part of a broad-based diet (Kibler and Scott 2000:134) or part of a generalized foraging strategy, an idea Prewitt (1981) put forth earlier. At times during the Late Archaic, this generalized foraging strategy appears to have been marked by shifts to a specialized economy focused on bison hunting (Kibler and Scott 2000:125-137). Castroville, Montell, and Marcos dart points are elements of tool kits often associated with bison hunting (Collins 1968). Archeological evidence of this association is seen at Bonfire Shelter in Val Verde County (Dibble and Lorrain 1968), Jonas Terrace (Johnson 1995), Oblate Rockshelter (Johnson et al 1962:116), John Ischy (Sorrow 1969), and Panther Springs Creek (Black and McGraw 1985).

The Archaic period represents a hunting and gathering way of life that was successful and that remained virtually unchanged for more than 7,500 years. This notion is based in part on fairly consistent artifact and tool assemblages through time and place and on resource patches that were used continually for several millennia, as the formation of burned rock middens shows. This pattern of generalized foraging, though marked by brief shifts to a heavy reliance on bison, continued almost unchanged into the succeeding Late Prehistoric period.

\section{Late Prehistoric Period}

Introduction of the bow and arrow and, later, ceramics into central Texas marked the Late Prehistoric period. Population densities dropped considerably from their Late Archaic peak (Prewitt 1985:217). Subsistence strategies did not differ greatly from the preceding period, although bison again became an important economic resource during the late part of the Late Prehistoric period (Prewitt 1981:74). Use of rock and earth ovens for plant-food processing and the subsequent development of burned rock middens continued throughout the Late Prehistoric period (Black et al. 1997; Kleinbach et al. 1995:795). Horticulture came into play very late in the region but was of minor importance to overall subsistence strategies (Collins 1995:385).

In central Texas, the Late Prehistoric period generally is associated with the Austin and Toyah phases (Jelks 1962; Prewitt 1981:82-84). Scallorn-Edwards arrow points, Austin horizon markers, are distributed across most of the state, as are Perdiz arrow points, which are Toyah phase horizon markers. Violence and conflict often marked introduction of Scallorn and Edwards arrow points into central Texas-many excavated burials contain Scallorn and Edwards points in contexts indicating they were the cause of death (Prewitt 1981:83). Subsistence strategies and technologies (other than arrow points) did not change much from the preceding Late Archaic period. Prewitt's (1981) use of the term "Neoarchaic" recognizes this continuity. In fact, Johnson and Goode (1994:39-40) and Collins (1995:385) state that the break between the Austin and Toyah phases could easily and appropriately represent the break between the Late Archaic and the Late Prehistoric.

Around 1000-750 B.P., slightly more-xeric or drought-prone climatic conditions returned to the region, and bison came back in large 
numbers (Huebner 1991; Toomey et al. 1993). Using this vast resource, Toyah peoples were equipped with Perdiz point-tipped arrows, end scrapers, four-beveled-edge knives, and plain bone-tempered ceramics. Toyah technology and subsistence strategies represent a completely different tradition from the preceding Austin phase. Collins (1995:388) states that formation of burned rock middens ceased as bison hunting and group mobility obtained a level of importance not witnessed since Folsom times. Although the importance of bison hunting and high group mobility hardly can be disputed, the argument that burned rock midden development ceased during the Toyah phase is tenuous. A recent examination of Toyah-age radiocarbon assays and assemblages by Black et al. (1997) suggests that their association with burned rock middens represents more than a "thin veneer" capping Archaic-age features. Black et al. (1997) claim that burned rock midden formation, although not as prevalent as in earlier periods, was part of the adaptive strategies of Toyah peoples.

\section{WORK ACCOMPLISHED AND METHODS OF INVESTIGATION}

The 2004 testing consisted of re-locating and re-excavating Trenches 5 and 6 from the 2004 survey. A single 15-m-long trench was then excavated from Trench 6 to Trench 5 , forming one 30-m-long north-south trench (Trench 7). To better define the site boundaries within the easement, a ca. 20-m-long trench (Trench 8 ) was from the center of Trench 7 eastward toward the edge of the easement. Two other trenches were also excavated to help define the site boundaries: Trench 9 was excavated upslope ca. $30 \mathrm{~m}$ north of Trench 7, and Trench 10 was ca. $5 \mathrm{~m}$ south of Trench 7 closer to Squaw Creek. About $20-30 \mathrm{~cm}$ of sterile overburden was removed from test unit locations so that hand excavation could focus on the cultural zone identified by previous investigations at 30$90 \mathrm{~cm}$ in Trenches 5 and 6 . Fourteen $50 \times 50-\mathrm{cm}$ units were then excavated from 20 or 30 to $100 \mathrm{~cm}$ below the ground surface, one $50 \times 50-\mathrm{cm}$ unit was excavated from 110 to $150 \mathrm{~cm}$ below the ground surface in the bottom of Trench 7 , and two 1x1-m units were dug from ca. $20-30 \mathrm{~cm}$ below the ground surface down to ca. $100 \mathrm{~cm}$ (Table 1; Figure 3). The 17 test units were exca- vated in 10-cm levels, and the volume of sediment manually excavated and screened totaled $4.35 \mathrm{~m}^{3}$. Placement of all units was predicated on locating cultural materials and possible features observed in various trenches. All units were placed beside backhoe trenches in areas deemed best for sampling cultural deposits. All materials removed were screened through $1 / 4-$ inch-mesh hardware cloth. Soil stratigraphy was recorded and described for all trenches and test units by the project archeologist.

All cultural materials recovered from 1/4inch-mesh screening were bagged in the field and then returned to PAI's laboratory. All relevant provenience data were labeled on each bag before it left the field. Artifact counts by test unit and level were recorded in the field to assist in tracking artifact frequencies and distributions across the site. Three burned rock features were recorded using a standard PAI Feature Form. The final step of fieldwork consisted of mapping the site's topographic features and the locations of all test units and trenches with an electronic total station (see Figure 3).

Lab processing took place during March 2005 and entailed washing, identifying, and cataloging all cultural materials recovered. The final laboratory step was flotation of all sediments removed from cultural features and collection of cultural materials in these samples (Table 2). Samples were processed using the Flote-Tech flotation system, which provides a multimodal method of separating materials into heavy and light fractions. For each sample, the heavy fraction was scanned to recover artifacts.

\section{SEDIMENTS AND STRATIGRAPHY}

Site 41SV153 is situated on a broad, nearly level flood terrace that stands ca. 6-7 $\mathrm{m}$ above the Squaw Creek channel. Mollisols of the Bosque soil series are mapped on the surface of the terrace (Coburn 1978). Three basic stratigraphic zones were observed throughout the trenches and test units (Figure 4). Zone 1 consisted of very dark grayish brown (10YR 3/2) to dark grayish brown (10YR 4/2) loam from the surface down to ca. $40 \mathrm{~cm}$. Zone 2 was a brown (7.5YR 4/6) sandy silty clay with alluvial gravels scattered throughout. A ca. 10-cm-thick lens of alluvial gravel was noted in Trench 10 in the upper $30 \mathrm{~cm}$ of Zone 2 . In several locations, 


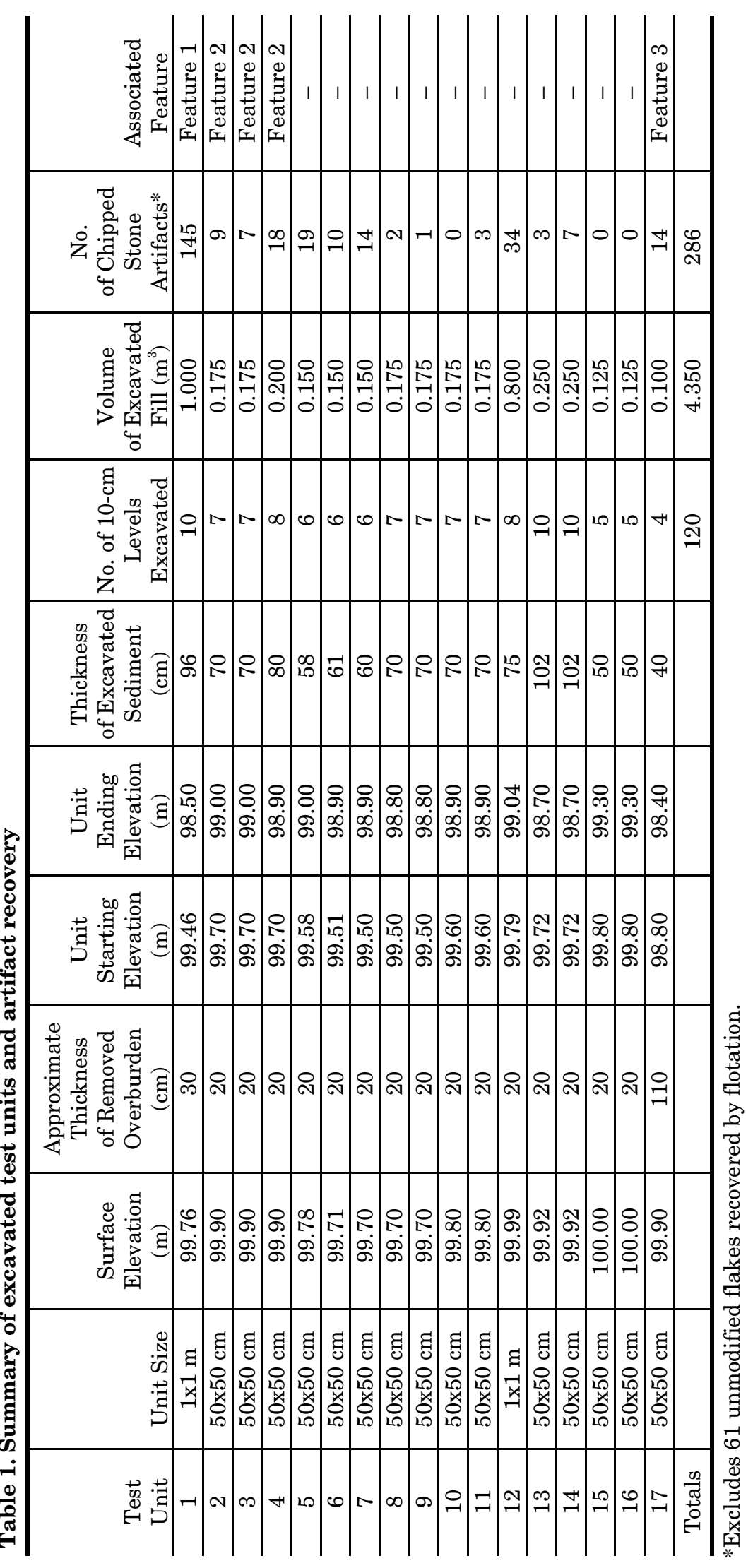




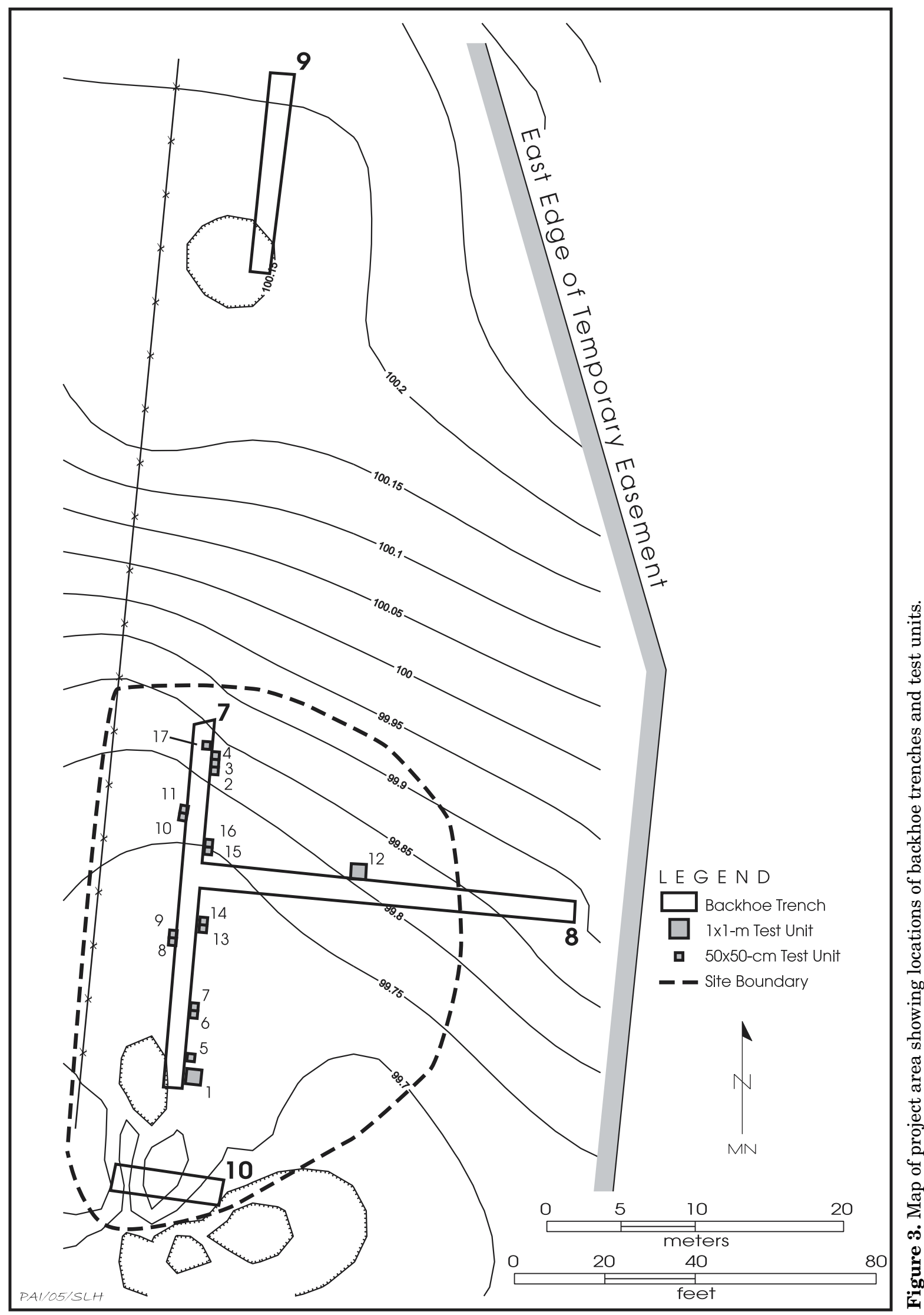


Table 2. Provenience of cultural materials recovered from flotation samples*

\begin{tabular}{c|l|c|c|c|c|c}
\hline $\begin{array}{c}\text { Test } \\
\text { Unit* }\end{array}$ & \multicolumn{1}{|c|}{$\begin{array}{c}\text { Sample } \\
\text { Provenience }\end{array}$} & $\begin{array}{c}\text { Volume of } \\
\text { Sample } \\
(\text { liters })\end{array}$ & $\begin{array}{c}\text { Unmodified } \\
\text { Flakes } \\
(<1 / 4 \text { inch })\end{array}$ & $\begin{array}{c}\text { Unmodified } \\
\text { Flakes } \\
(>1 / 4 \text { inch) }\end{array}$ & $\begin{array}{c}\text { Total } \\
\text { Unmodified } \\
\text { Flakes }\end{array}$ \\
\hline 1 & $\begin{array}{l}\text { Feature 1 in west } \\
\text { half of unit }\end{array}$ & $99.09-98.96$ & 9.00 & 19 & 0 & 19 \\
\hline 1 & $\begin{array}{l}\text { Feature 1 in east } \\
\text { half of unit }\end{array}$ & $99.09-98.89$ & 8.50 & 20 & 5 & 25 \\
\hline 3 & Feature 2 & $99.41-99.38$ & 1.00 & 1 & 0 & 1 \\
\hline 4 & Feature 2 & $99.39-99.31$ & 1.00 & 2 & 0 & 2 \\
\hline 4 & Feature 2 & $99.35-99.30$ & 0.75 & 5 & 1 & 6 \\
\hline 4 & Feature 3 & $99.35-99.16$ & 4.25 & 8 & 0 & 8 \\
\hline Total & & & & 55 & 6 & 61 \\
\hline
\end{tabular}

*No macrobotanical remains were recovered

degraded limestone gravels and carbonate nodules were present in this zone. An abrupt boundary separates these upper two zones from Zone 3 . The boundary between Zones 2 and 3 revealed in trench and test unit profiles consists of an undulating relict erosional surface. It is a gravelly sandy very silty clay with abundant carbonate nodules and degraded limestone gravels.

The mixing of Zones 2 and 3 sediments was observed in areas where Zone 3 dipped downward. This suggests that the upper Zone 2 sediments aggraded slowly over time, allowing for mixing of the sediments in low-lying places because of slopewash. The lower portion of the Zone 2 sediments follows the undulating nature of the relict surface. All cultural materials were restricted to the upper two zones. In some areas of the site, such as Test Unit 17, the cultural materials within Zone 2 appear to be lying on the sloping surface that follows the slope of the underlying Zone 3 deposit. The varying depths of the Zone $2 / 3$ contact account for the recovery of cultural materials at lower elevations in some areas.

\section{CULTURAL MATERIALS AND FEATURES}

Cultural materials collected consist of chipped stone tools, lithic debitage, a core, one animal bone, and burned rocks (Table 3). Unmodified lithic debitage is by far the most abundant artifact type, with 278 pieces. Chipped stone tools consist of 2 projectile points, 3 biface fragments, and 1 edge-modified flake. A single bone and one core were recovered as well. The single bone is not identifiable beyond the vertebrate category and appears to be intrusive.
Burned rocks were common. Most of these were associated with cultural features or a dense lens present in several of the trenches. These materials were not collected but were quantified in the field.

Three features were exposed and excavated. Two of these were between 99.30 and $98.89 \mathrm{~m}$ in elevation, and the other was between 98.35 and $98.16 \mathrm{~m}$. No charcoal was recovered from any feature. Matrix was collected in bulk from all features for flotation, but charcoal or other organic materials were retrieved.

Feature 1 was in Test Unit 1 between 99.16 and $98.89 \mathrm{~m}$. It consisted of a dense burned rock scatter that covered most of the floor of the $1 \times 1$ $\mathrm{m}$ unit (Figure 5). The scatter sloped gently to the south and extended both east and south of Test Unit 1 . The rocks consisted of both tabular and water-worn limestone cobbles. Many of the smaller rocks appeared to be fire-reddened fragments. Several of the larger rocks were found with one reddened surface on the bottom, top, or side. All of the rocks appeared to be jumbled, with no recognizable patterns in the placement of rocks or the locations of heat discoloration. Two biface fragments and 36 pieces of debitage were recovered from the feature. A total of $134.1 \mathrm{~kg}$ of rocks were removed from this feature. Forty-four pieces of debitage were collected from the 17.5 liters of feature matrix during flotation. No charcoal or other organic materials were recovered from this feature. Although obviously disturbed, based on the thermal alteration, size, and shape of the burned rocks the feature appears to have been associated with cooking activities.

Feature 2 was in Test Units 2, 3, and 4 between 99.52 and $99.29 \mathrm{~m}$. This feature sloped 


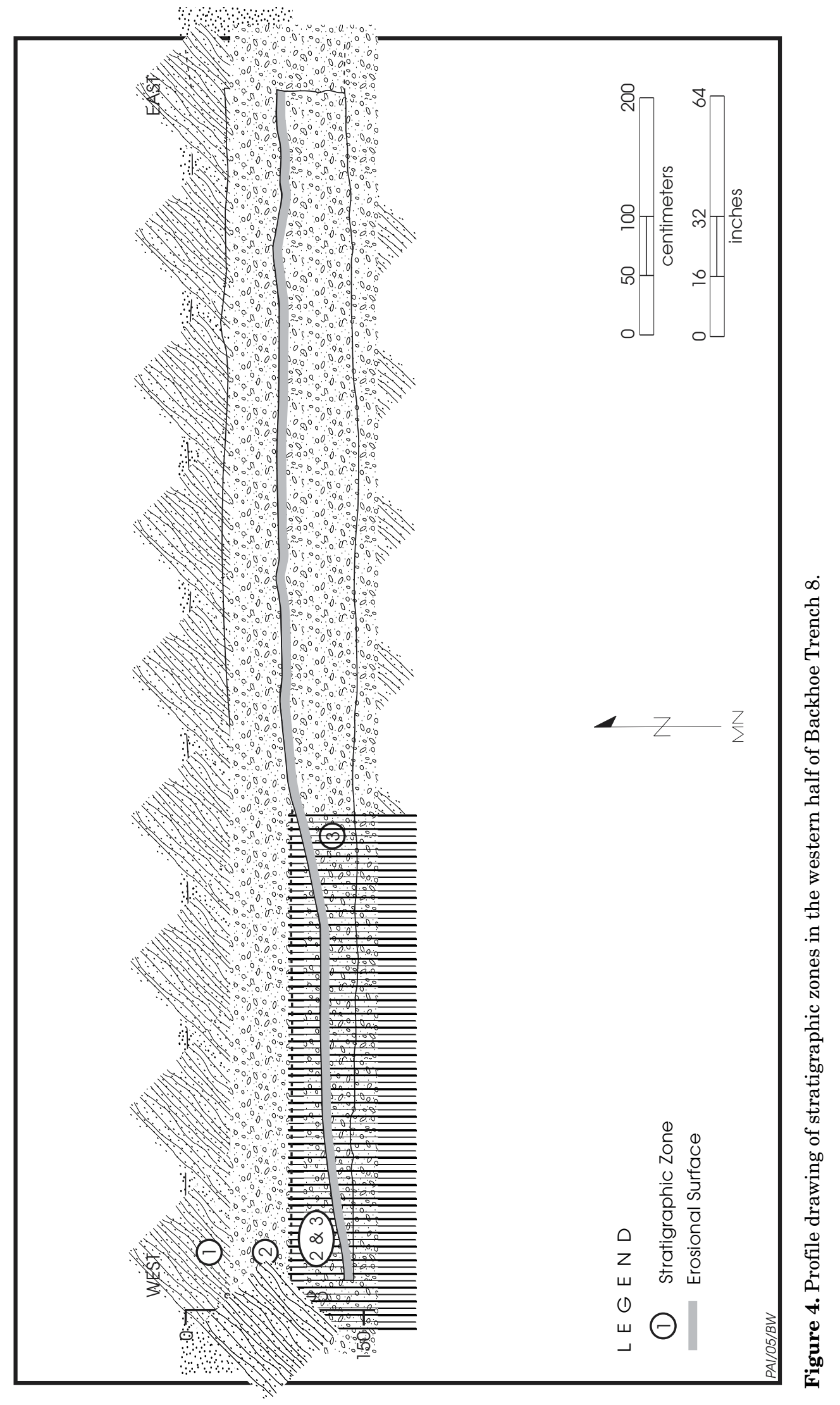




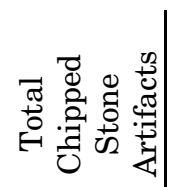

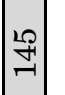

.

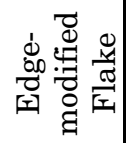

○

0

$\circ$

*

$\circ$

$0-1$

N

o

○

N

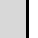

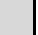

It

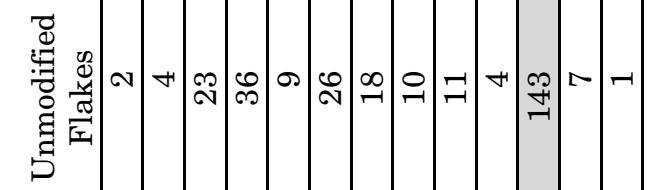

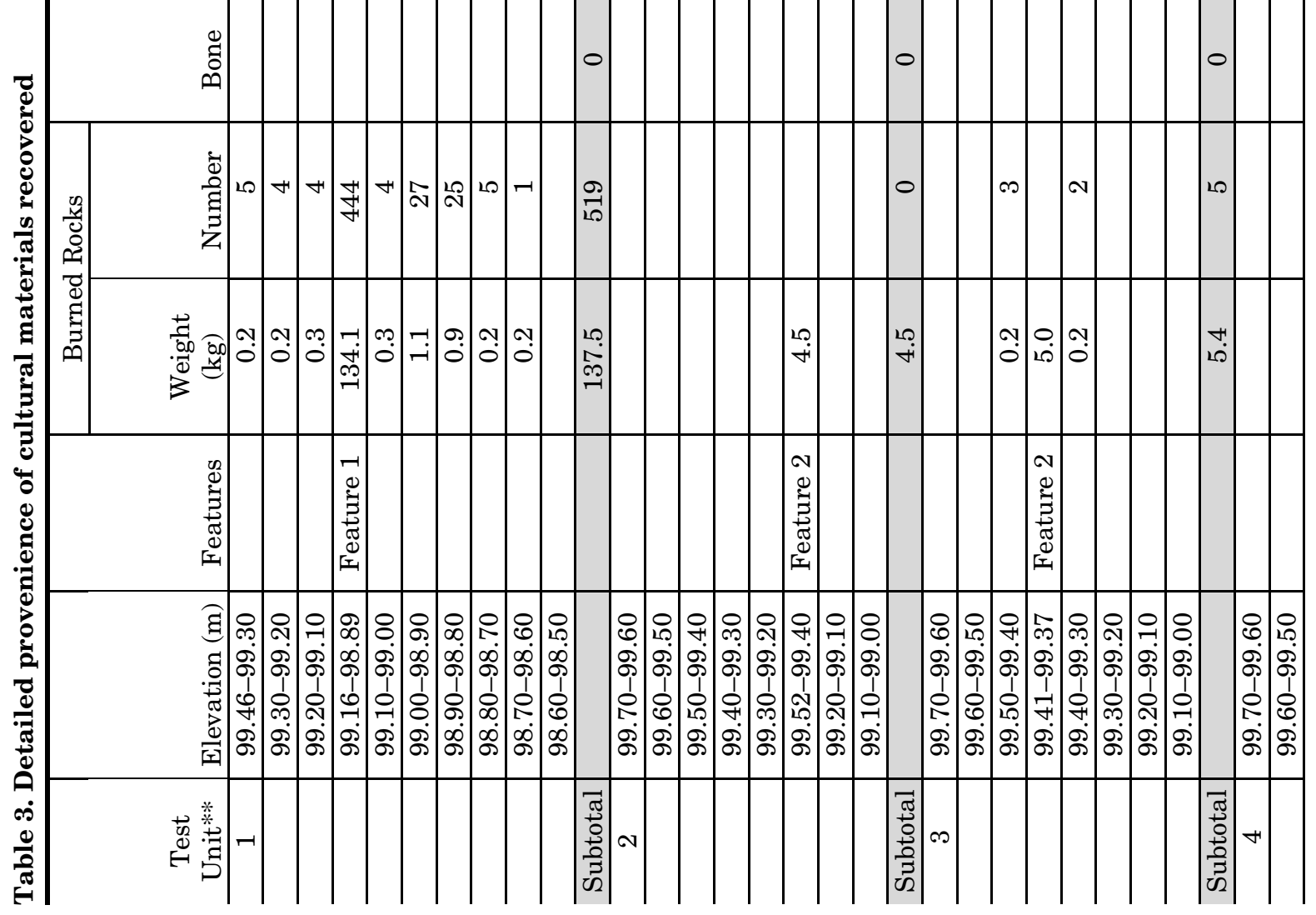




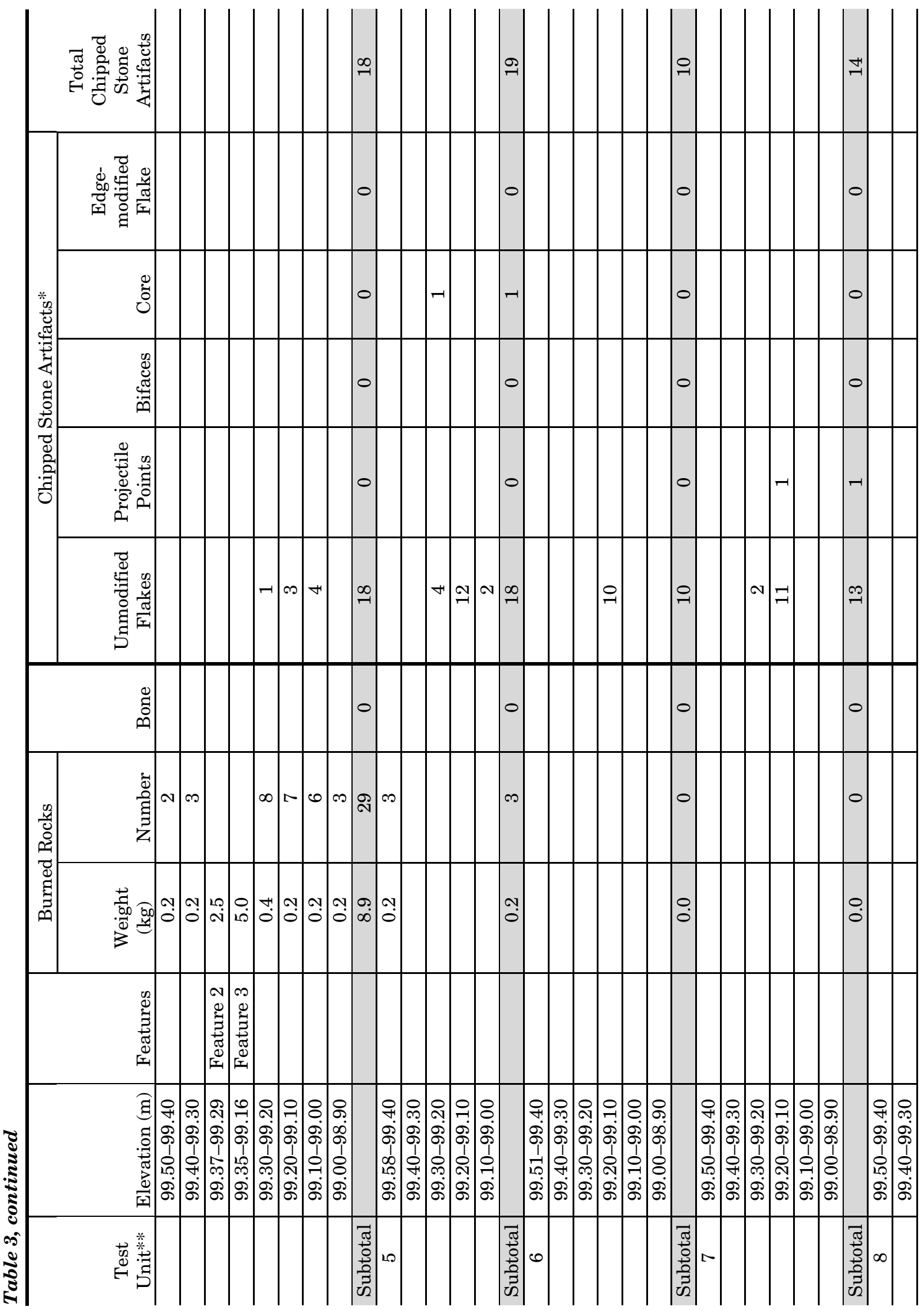




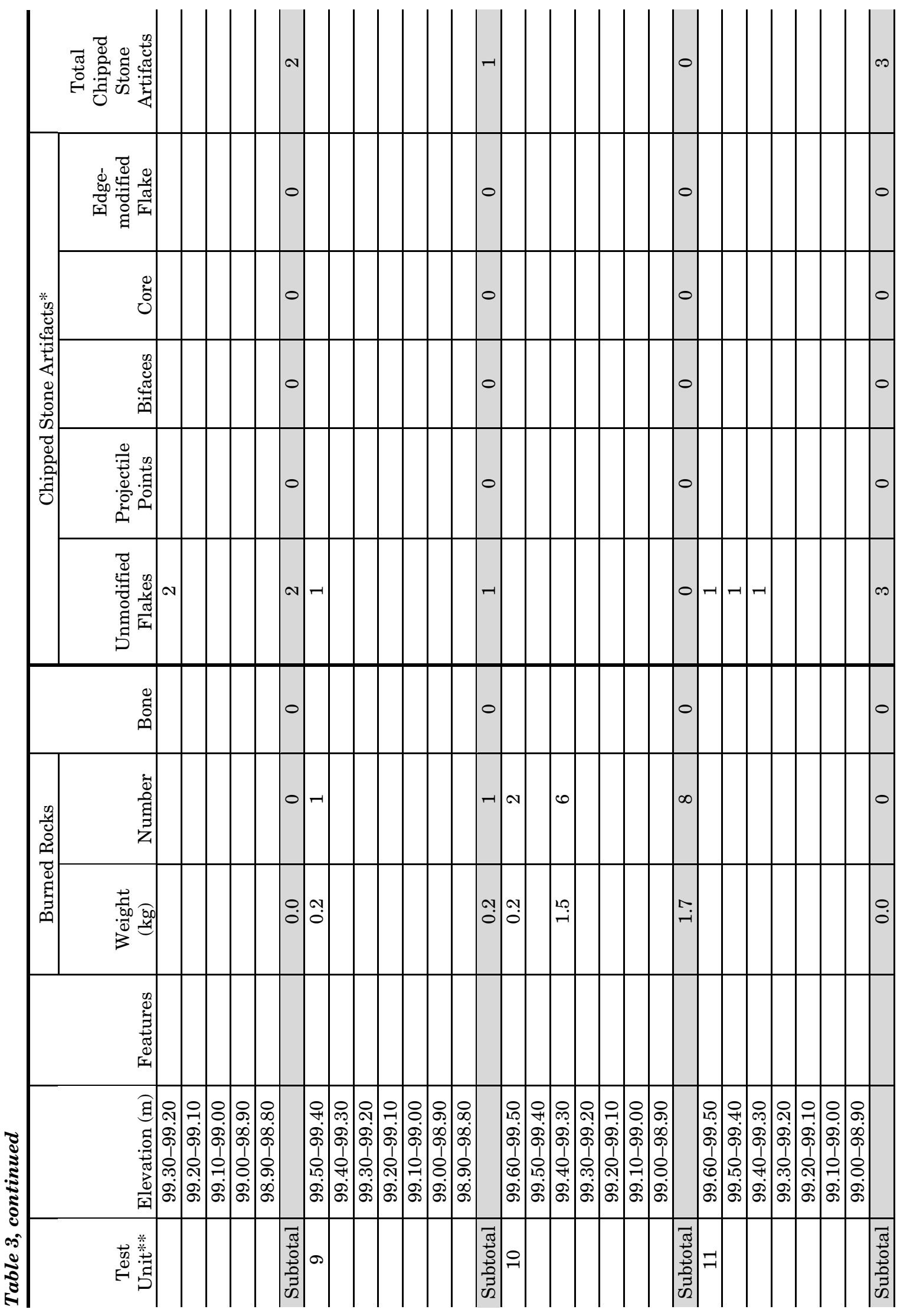




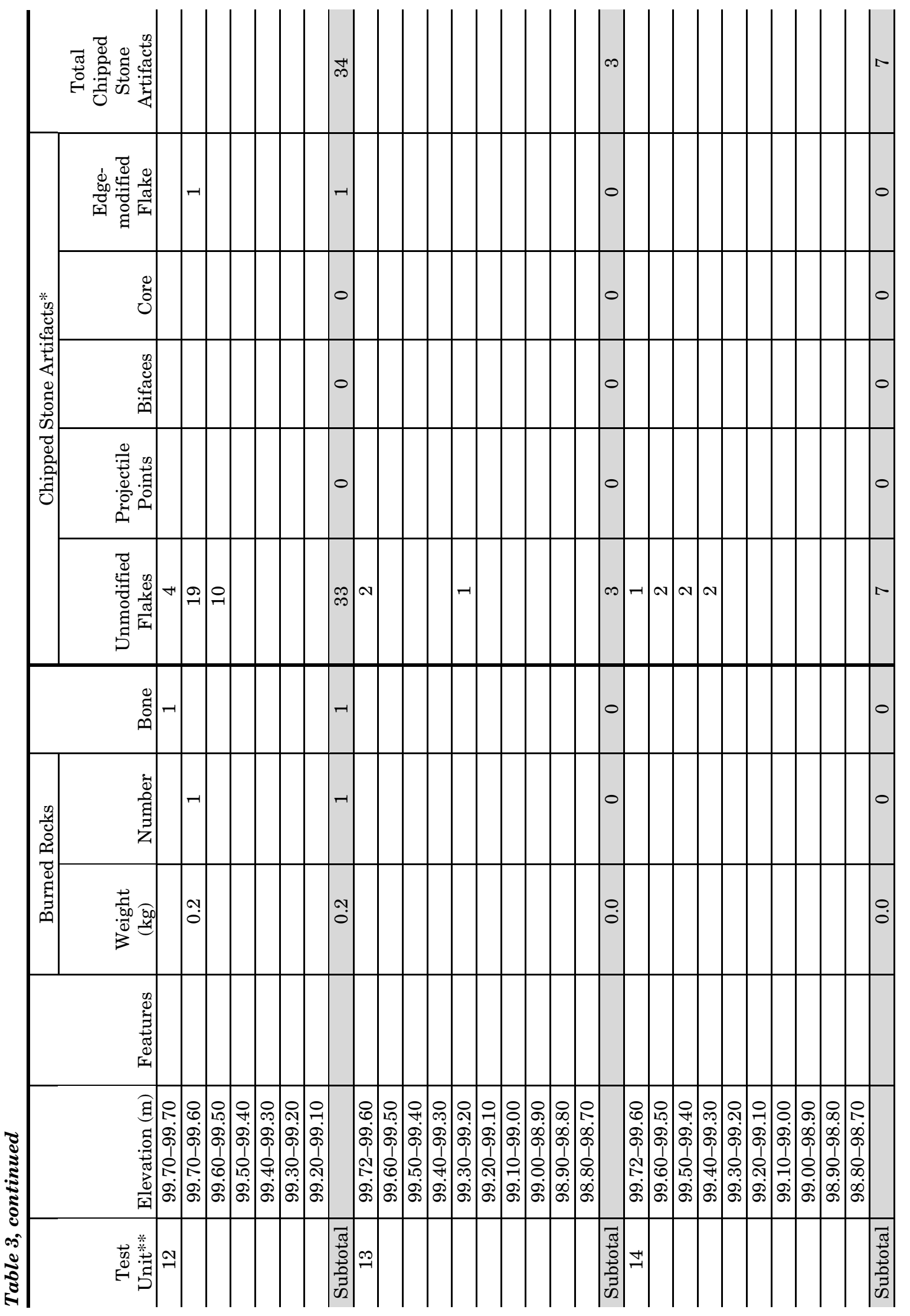




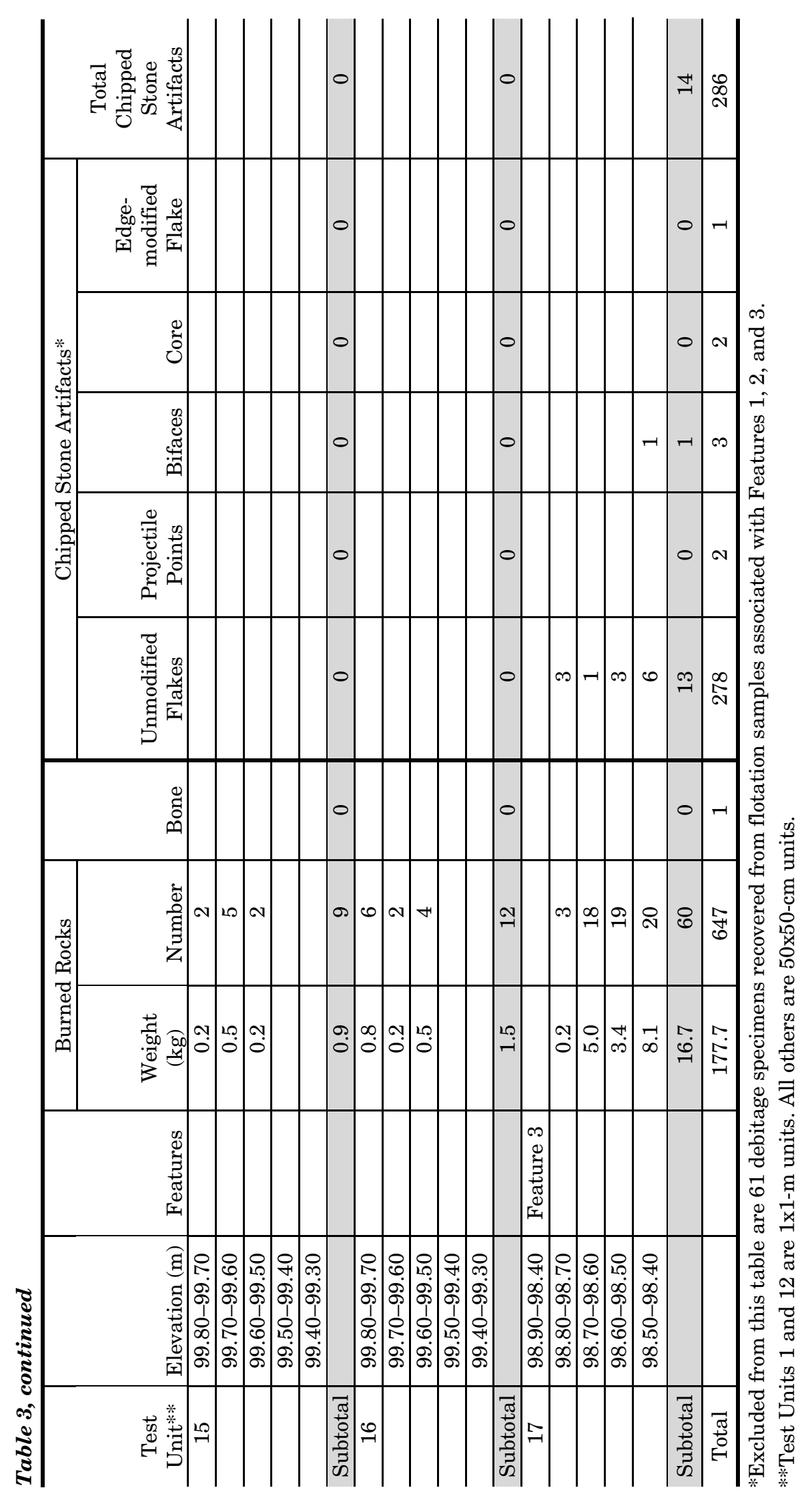




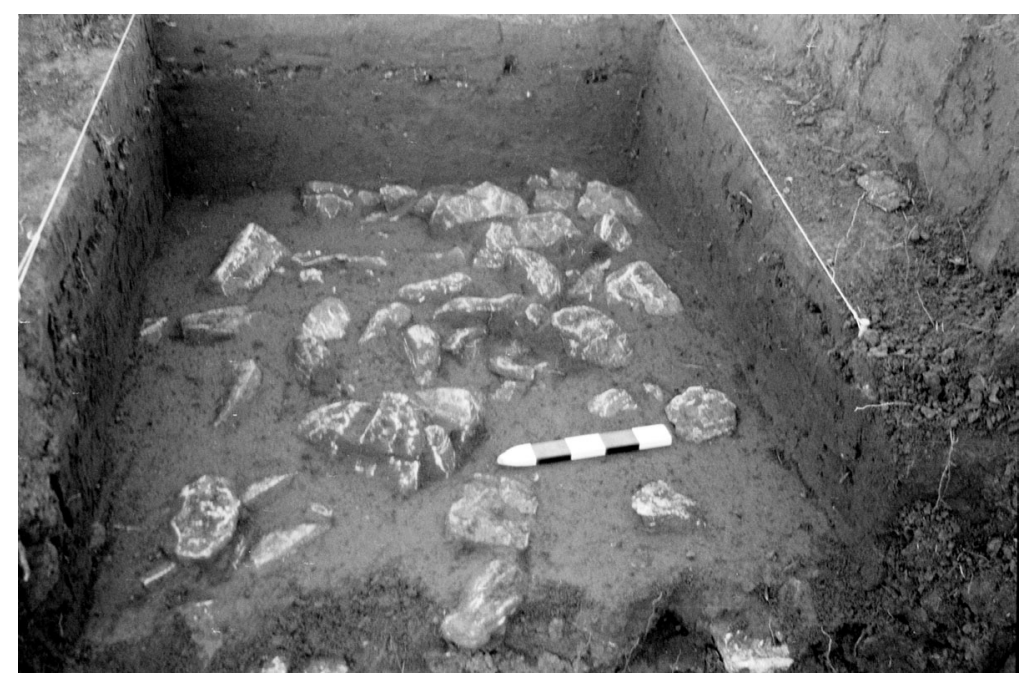

a

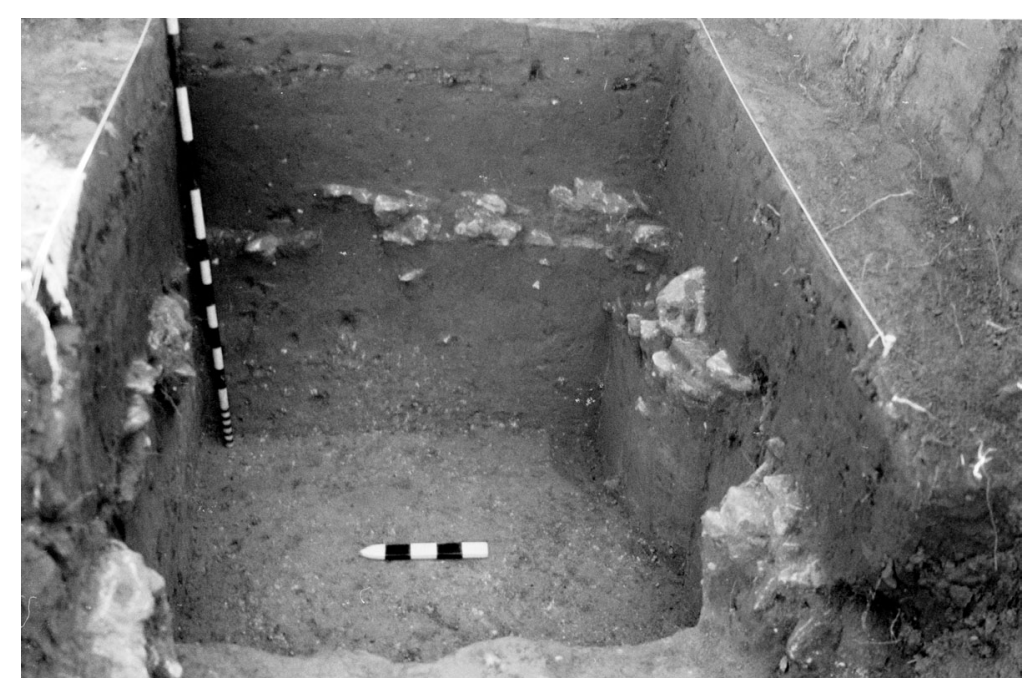

b

Figure 5. Feature 1 in Test Unit 1 looking east. (a) Feature rocks exposed in floor of at $99.00 \mathrm{~m}$; (b) feature rocks exposed in profile.

of the rocks and the thermal alterations suggest that Feature 2 was associated with cooking activities.

Feature 3 was in Test Unit 17 and on the sloping floor of Backhoe Trench 5 at the north edge of Test Unit 4 between 99.35 and $98.40 \mathrm{~m}$ (Figure 7). This feature was possibly associated with Feature 2, perhaps representing rocks moved downslope from Feature 2. It consisted of a concentration of burned rocks and an irregular scatter of burned rocks along the trench wall. The rocks were mostly subangular and tabular, with minimal discoloration because of burning. A total of $5.0 \mathrm{~kg}$ of burned rocks were removed from this feature. Most of the rocks were between 3 and $10 \mathrm{~cm}$ in length. No identifiable patterning in the placement of rocks was observed. Flotation of 4.25 liters of feature fill recovered eight pieces of debitage. No charcoal or other organic matter was recovered.

Only 347 artifacts were recovered from 41SV153: 6 chipped stone tools, 278 pieces of debitage, 2 cores from 1/4-inch screening, and 61 pieces of debitage from flotation. Detailed analysis was done only on the $1 / 4$-inch-screen sample. Recorded debitage attributes consist of flake type, dor-

down from south to north. It consisted of a small scatter of burned rocks along the western edges of all three test units (Figure 6). Most of the rocks were subangular, with larger tabular pieces present. The rocks appeared to be more heavily burned on the bottom. No distinct patterning was observed in placement of the rocks, and several appeared to be on a sloping surface. The feature continued north of Test Unit 4 in the east wall of Backhoe Trench 5 and into the floor of the trench. A total of $8.0 \mathrm{~kg}$ of burned rocks were removed from this feature. Flotation of 2.75 liters of feature fill yielded nine pieces of debitage. No charcoal or other organic materials were recovered from this feature. The size sal cortex percentage, cortex type, chert grain size, chert type, and maximum dimension. The different flake types are complete flakes, which have striking platforms and hinged or feathered terminations; proximal fragments, which have striking platforms but lack hinged or feathered terminations; chips, which are medial or distal flake fragments without striking platforms; and chunks, angular debris that lack flake attributes altogether. For chipped stone tools like projectile points, metrics were recorded when possible.

\section{Chipped Stone Tools}

Chipped stone tools consist of two projectile 


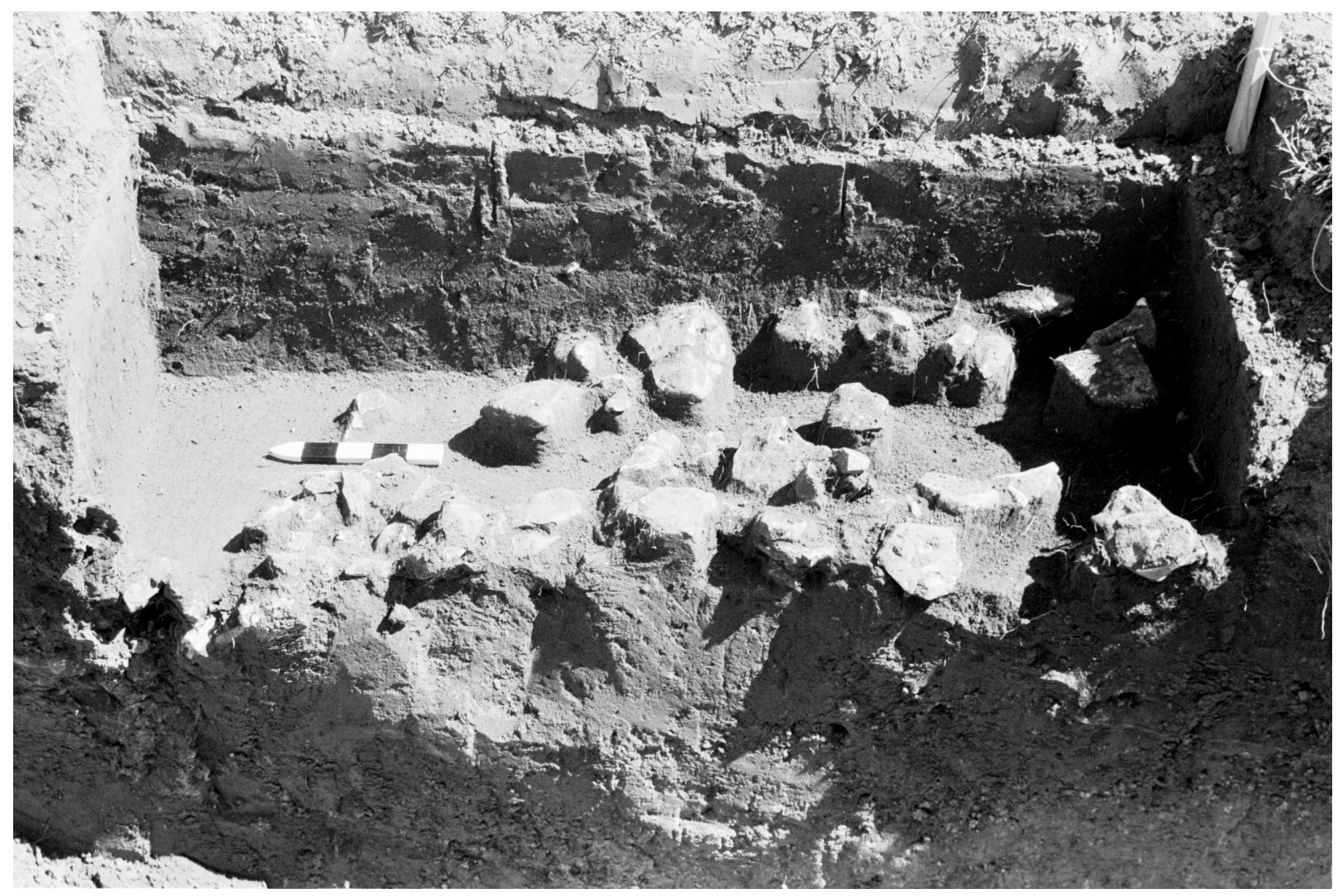

Figure 6. Feature 2 in Test Unit 2. View is to the east at elevation $99.52 \mathrm{~m}$.

points, three biface fragments, and one edgemodified flake. Both of the projectile points (Figure 8) have been extensively reworked, hampering typological classification and temporal identification. However, each of the points exhibits several characteristics of certain projectile point types. One of the specimens is likely a reworked Hoxie point. It is $35.1 \mathrm{~mm}$ long, $20.8 \mathrm{~mm}$ wide, and $6.0 \mathrm{~mm}$ thick. Reworking has removed all traces of a basal stem similar to the Hoxie illustrated by Dial et al. (1998) from the Wilson-Leonard site. The second specimen is $34.8 \mathrm{~mm}$ long, $16.1 \mathrm{~mm}$ wide, and $8.1 \mathrm{~mm}$ thick and exhibits grinding along a straight stem that is similar to the base of a Darl point. Although lacking a concave base, this point is also similar to some reworked Hoxie points recorded by Prewitt (1982) at the Tombstone Bluff site (41WM165).

Three biface fragments were recovered from Test Units 1 and 17. It is difficult to tell what these tools were used for, however, two appear to be large projectile fragments and one appears to be a crude blank. No evidence of use wear is noticeable on the edges of these bifaces. The one edge-modified flake exhibits modification from use. It contains ca. 50 percent dorsal cortex. It is difficult to tell what this tool was used for, but it was probably for expedient tasks.

\section{Debitage and Cores}

A total of 278 pieces of unmodified debitage were recovered. Of those, 80 percent $(n=222)$ are chips, 6 percent $(\mathrm{n}=18)$ are chunks, 8 percent $(n=23)$ are complete flakes, and 5 percent $(\mathrm{n}=15)$ are proximal flake fragments. Cortex is present on 73 pieces, and 66 percent of these appear to be from secondary gravel sources. The remainder are probably from primary (bedrock) outcrops. Most of the unmodified debitage $(\mathrm{n}=205,74$ percent $)$ has no dorsal cortex. Fiftyfour pieces have less than 50 percent, and only 19 pieces have more than 50 percent cortex. Many complete flakes entirely lack cortex (74 percent), and 19 percent have less than 50 percent. In terms of size, 63 percent of the debitage falls between 20 and $30 \mathrm{~mm}$. Most of the chips $(\mathrm{n}=142)$ are between 11 and $30 \mathrm{~mm}$. Complete flakes are equally distributed between 11 and $40 \mathrm{~mm}$. Most of the chunks $(\mathrm{n}=8)$ are between 11 and $20 \mathrm{~mm}$. Proximal flakes fall 


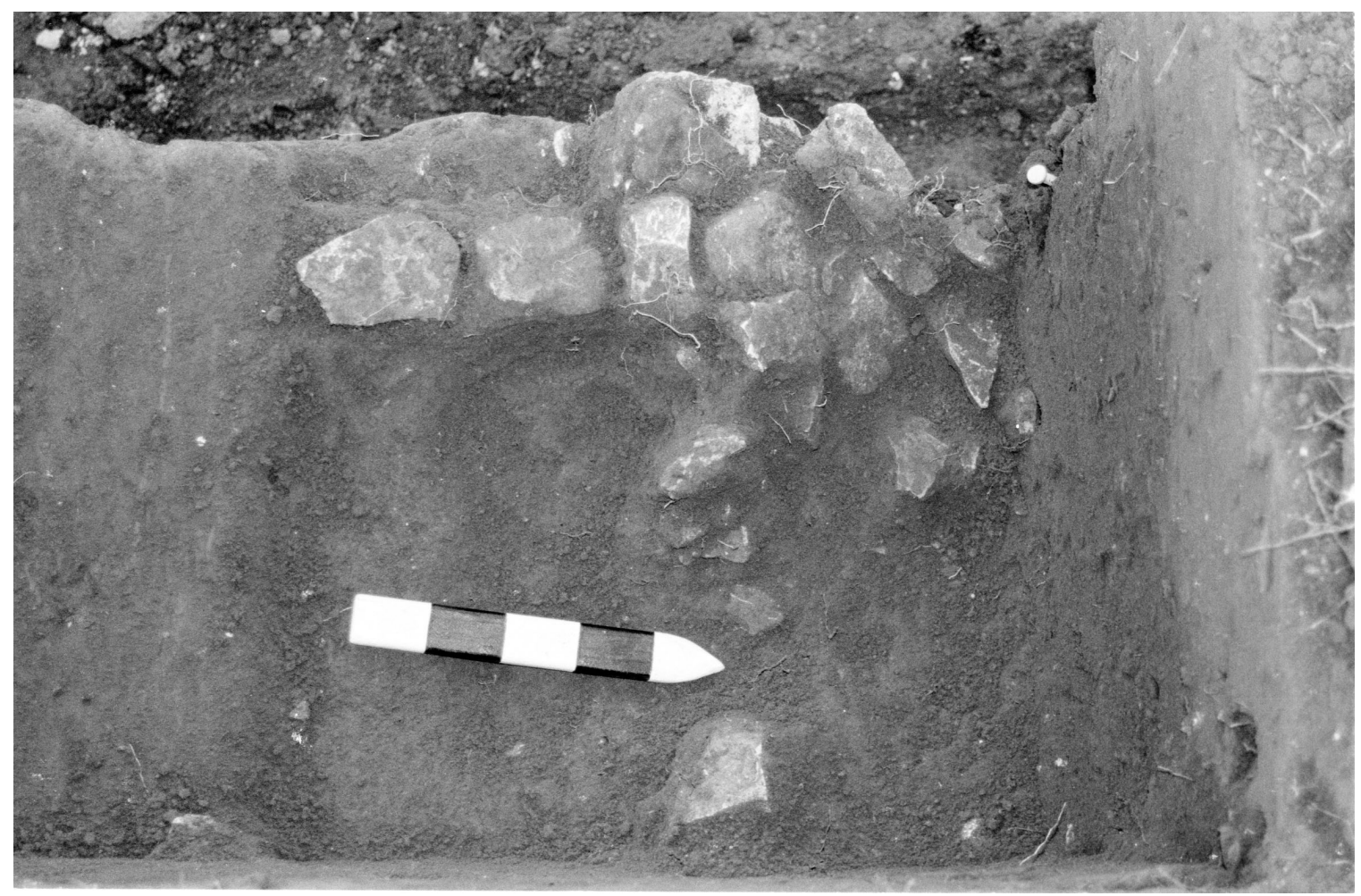

a

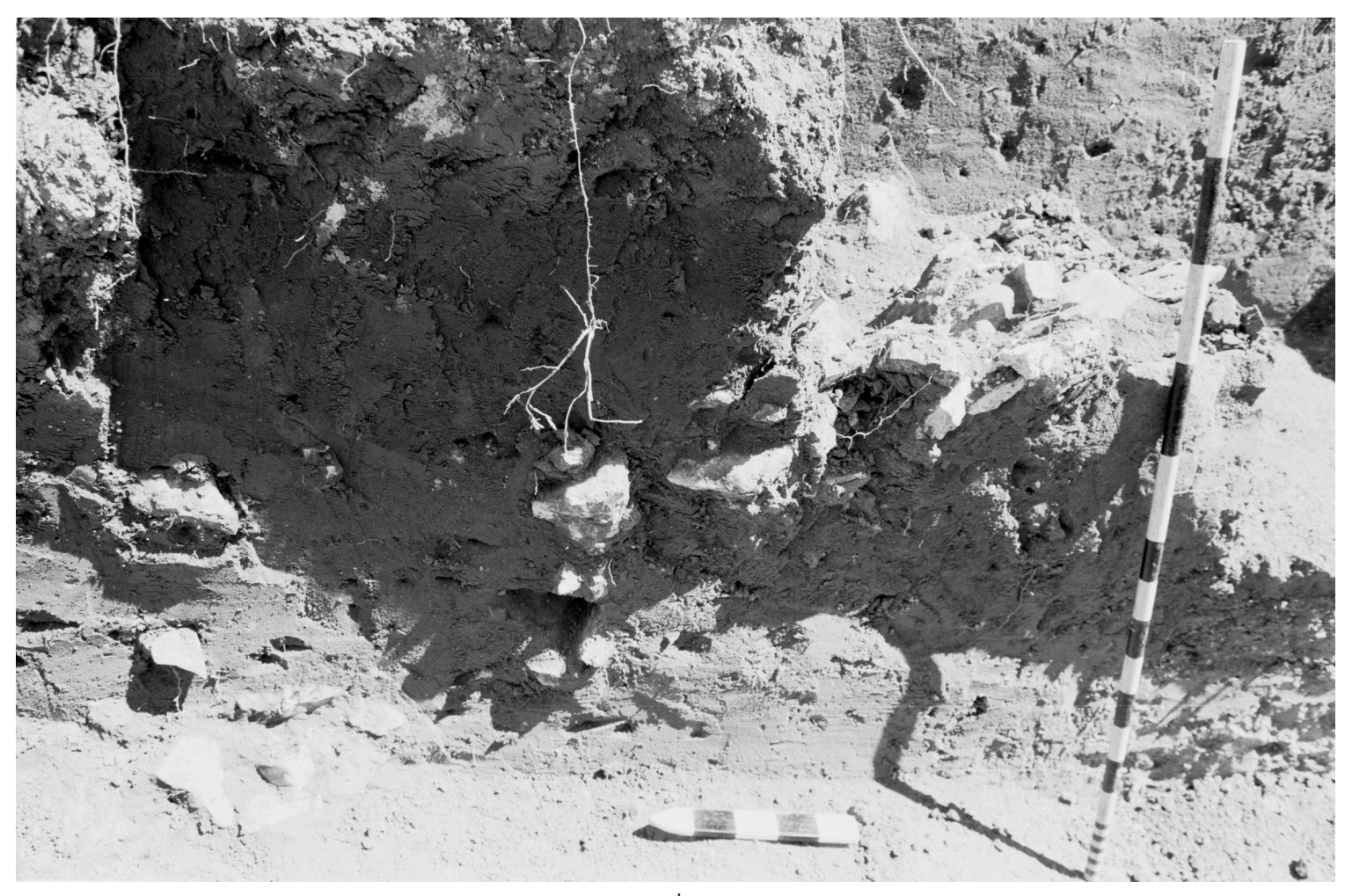

b

Figure 7. Feature 3 in Test Units 4 and 17. (a) Overhead view looking west of feature rocks in Test Unit 4 at elevation 99.35; (b) view east of feature rocks exposed in Test Unit 17 at $98.70 \mathrm{~m}$. 


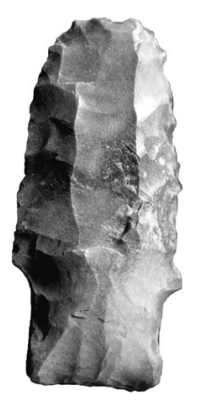

a
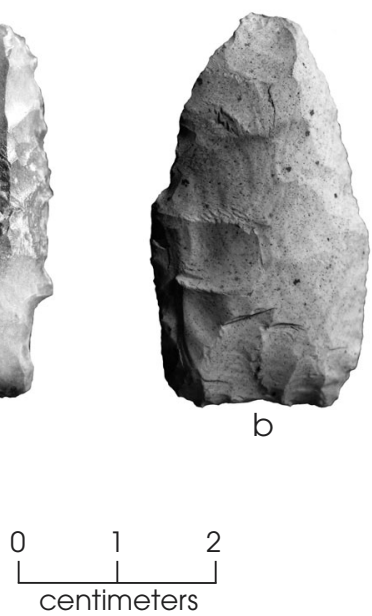

Figure 8. Projectile points recovered. (a) Reworked Hoxie point. (b) possible Darl point.

mostly between 11 and $20 \mathrm{~mm}$. Overall, 88 percent of the unmodified debitage is less than $30 \mathrm{~mm}$ in size, and 62 percent is $20 \mathrm{~mm}$ or less.

Only 33 pieces of the unmodified debitage show thermal alterations. One of these has signs of crazing, three have discoloration and potlids, and three have discoloration and crazing. In contrast to these seven specimens, the other 26 flakes exhibit only discoloration from heating at low temperatures. Thus, it appears that approximately 9 percent of the debitage could represent intentional heat -treating.

Two cores were recovered. One of the specimens is crude and exhibits natural fractures. The other specimen is complete and exhibits several flake scars. No evidence of bashing or crushing is evident on either core.

\section{ANALYSIS OF FEATURE AND ARTIFACT DISTRIBUTIONS}

This section presents an analysis of the horizontal and vertical distributions of features and artifacts. Cultural materials are most abundant in Test Unit 1, which yielded more pieces of debitage than all other test units combined. Test Unit 12 yielded the second-most debitage with 33 pieces. It should be noted that Test Units 1 and 12 were the only two $1 \times 1-m$ units; all other units were $50 \times 50 \mathrm{~cm}$. Test Units 4 and 5 both yielded 18 pieces of debitage, with 1 core coming from Test Unit 5 . Two bifaces were recovered from Test Unit 1 and 1 from Test Unit 17.
One projectile point was recovered from Test Unit 2, and 1 was recovered from Test Unit 7. When density of chipped stone artifacts per cubic meter is compared for all the test units, a different picture emerges (Table 4, Figure 9). Only five test units-Test Units 1, 4, 5, 7 and 17-have chipped stone densities between 90 and 145 per cubic meter. All the other test units have densities of 67 or less. Artifact recovery was so sparse and scattered in most units that patterns in vertical distributions are not observable. However, cultural material frequency decreases drastically below $99.00 \mathrm{~m}$. Other than Test Units 1 and 17, no cultural materials were recovered from any test unit below $99.00 \mathrm{~m}$.

The highest number of burned rocks was located in Test Unit 1 with 519 (137.5 kg), and the next highest was in Test Unit 17 with 60 $(16.7 \mathrm{~kg})$. This is not surprising because Feature 1 was located in Test Unit 1 and portions of Feature 3 were in Test Unit 17. Test Unit 4 contained $29(8.9 \mathrm{~kg})$ burned rocks and was associated with Feature 2 and portions of Feature 3. For the most part, burned rocks were lightly scattered throughout the rest of the site. None were in Test Units $6-8,11$, and $13-14$. When densities of burned rocks are compared, Test Unit 17 with Feature 3 contained 167.0 per cubic meter, and Test Unit 1 with Feature 1 contained 137.5 per cubic meter (see Figure 9). Test Units $2-4$ contained between 25 and $45 \mathrm{~kg}$ per cubic meter. Test Unit 2 and 3 each contained a portion of Feature 2, and Test Unit 4 contained portions of Features 2 and 3 . All other test units contained less than $12 \mathrm{~kg}$ cubic meter, with Test Units 6-8, 11, and 15-16 containing none.

Vertical and horizontal distributions suggest that most of the burned rocks were associated with disturbed features, but it is not possible to identify the functions of these features. No discrete patterning is observed in the vertical or horizontal distributions of nonfeature burned rocks. However, all burned rocks at 41SV153 are located within sediment Zones 1 and 2, as are all of the artifacts.

The distributions of the cultural materials and features suggest that the deposits associated with $41 \mathrm{SV} 153$ are ca. $100 \mathrm{~cm}$ thick in limited areas. Most of the site is restricted to a ca. $70 \mathrm{~cm}$ thick zone, though. The cultural zone is present between 99.70 and $98.50 \mathrm{~m}$ in Test Units 1 and 17 and between 99.70 and 99.00 in the other test units. Cultural materials were 
Table 4. Densities of burned rocks and artifacts by test unit

\begin{tabular}{|c|c|c|c|c|c|c|}
\hline $\begin{array}{l}\text { Test } \\
\text { Unit }\end{array}$ & $\begin{array}{c}\text { Associated } \\
\text { Feature }\end{array}$ & $\begin{array}{c}\text { Volume of } \\
\text { Excavated Fill } \\
\left(\mathrm{m}^{3}\right)\end{array}$ & $\begin{array}{c}\text { Total Burned } \\
\text { Rock Weight } \\
(\mathrm{kg})\end{array}$ & $\begin{array}{c}\text { Total No. of } \\
\text { Chipped Stone } \\
\text { Artifacts }\end{array}$ & $\begin{array}{c}\text { Burned Rocks } \\
(\mathrm{kg}) \text { per m }\end{array}$ & $\begin{array}{c}\text { Chipped Stone } \\
\text { Artifacts (No.) } \\
{\text { per } \mathrm{m}^{3}}^{3} \\
\end{array}$ \\
\hline $1^{*}$ & Feature 1 & 1.000 & 137.5 & 145 & 137.5 & 145.0 \\
\hline 2 & Feature 2 & 0.175 & 4.5 & 9 & 25.7 & 51.4 \\
\hline 3 & Feature 2 & 0.175 & 5.4 & 7 & 30.9 & 40.0 \\
\hline 4 & $\begin{array}{c}\text { Features } 2 \\
\text { and } 4\end{array}$ & 0.200 & 8.9 & 18 & 44.5 & 90.0 \\
\hline 5 & - & 0.150 & 0.2 & 19 & 1.3 & 126.7 \\
\hline 6 & - & 0.150 & 0.0 & 10 & 0.0 & 66.7 \\
\hline 7 & - & 0.150 & 0.0 & 14 & 0.0 & 93.3 \\
\hline 8 & - & 0.175 & 0.0 & 2 & 0.0 & 11.4 \\
\hline 9 & - & 0.175 & 0.2 & 1 & 1.1 & 5.7 \\
\hline 10 & - & 0.175 & 1.7 & 0 & 9.7 & 0.0 \\
\hline 11 & - & 0.175 & 0.0 & 3 & 0.0 & 17.1 \\
\hline $12^{*}$ & - & 0.800 & 0.2 & 34 & 0.3 & 42.5 \\
\hline 13 & - & 0.250 & 0.0 & 3 & 0.0 & 12.0 \\
\hline 14 & - & 0.250 & 0.0 & 7 & 0.0 & 28.0 \\
\hline 15 & - & 0.125 & 0.9 & 0 & 7.2 & 0.0 \\
\hline 16 & - & 0.125 & 1.5 & 0 & 12.0 & 0.0 \\
\hline 17 & Feature 3 & 0.100 & 16.7 & 14 & 167.0 & 140.0 \\
\hline Total & & 4.350 & 177.7 & 286 & - & - \\
\hline Average & & - & - & - & 40.8 & 65.7 \\
\hline Range & & - & - & - & $0.0-167.0$ & $0.0-145.0$ \\
\hline
\end{tabular}

* Denotes 1x1-m unit; all others are 50x50-cm units.

completely absent from Test Units 15 and 16 . The cultural zone consists of only a limited amount of cultural materials and disturbed features. No charcoal or other organic materials for dating were recovered. The two projectile points found are similar to Hoxie and Darl points, suggesting that the site may in the Early Late Archaic periods, but the lack of radiocarbon dates makes it impossible to confirm this.

Flotation of feature matrix from the features did not significantly increase the counts for artifact categories (see Tables 2 and 3). Lithic debitage was increased by only 61 pieces. No other cultural materials were recovered from flotation.

\section{SUMMARY OF INTERPRETATIONS}

Archeological testing of 41SV153 produced limited cultural materials and little data useful for interpreting site function, subsistence technologies, and chronology. The sample of lithic tools is too small to be very informative about site function. Lacking any plant or animal remains (excluding a single bone that is probably recent), no subsistence interpretations are offered. Similarly, little can be said about the time of the people who occupied 41SV153. In the absence of any datable organic remains, the projectile points allow only for a crude temporal assessment. The vertical distribution of materials make it seem certain that the site was occupied occasionally over a long period of time, but there is no way of knowing how many occupations are represented or the total span of time over which the site was occupied.

Three disturbed burned rock features were found, and scattered burned rocks were present throughout the cultural deposits. The function of these features cannot be determined, however, and the excavations revealed no apparent patterning in the burned rock distributions. It is likely that the features and scattered burned rocks simply represent surface hearths that were disturbed by natural and cultural processes. Although the use of burned rock middens was common in the region in Archaic times, the 


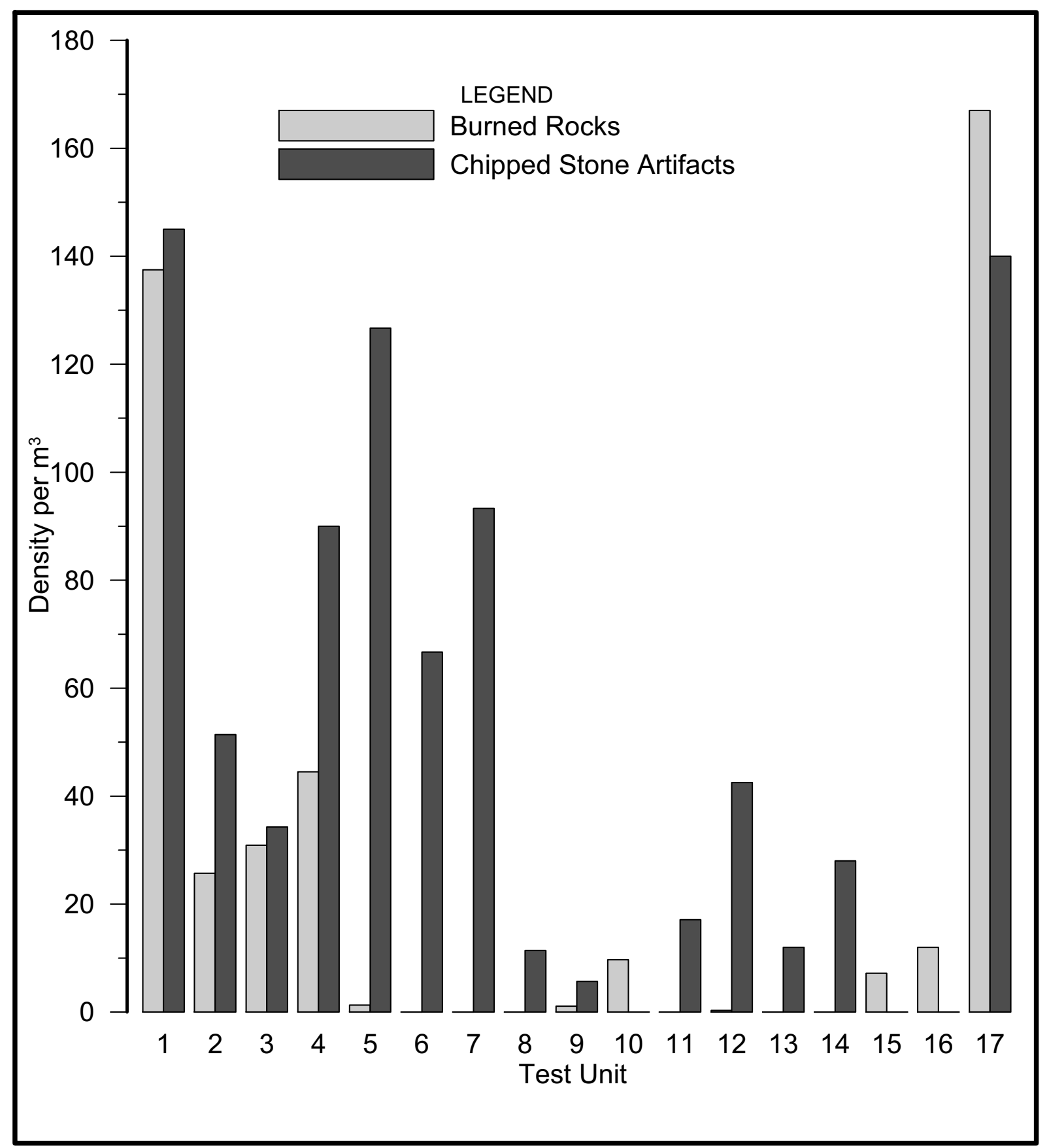

Figure 9. Comparison of densities of burned rocks and chipped stone artifacts by test unit.

relatively small quantities of burned rocks and lack of intrusive rock-lined pits indicate that no such activities occurred at 41SV153.

The lithic artifacts suggest that the prehistoric inhabitants used available cherts procured mainly from secondary gravel sources but also from primary bedrock outcrops. Very little of the chert (ca. 9 percent) brought onto the site was intentionally heat treated. Several factors sug- gest that late-stage lithic reduction activities were prevalent at 41SV153. No primary flakes were found, and tertiary flakes (74 percent) are much more common than secondary flakes (36 percent). The fact that only one core was recovered is further evidence of a focus on latestage reduction activities. Flake size and platform attributes (the latter not quantified) suggest that most of the lithic activities involved 
reducing bifaces, and it is likely that most of the materials were already reduced to biface form before being brought to the site.

\section{REGIONAL GEOARCHEOLOGICAL RESEARCH ISSUES}

The cultural remains at $41 \mathrm{SV} 153$ are buried within Holocene-age terrace deposits of Squaw Creek, and three stratigraphic zones were identified in the trench and unit exposures. Zones 1 and 2 are Holocene deposits between 80 and $120 \mathrm{~cm}$ thick, and all of the cultural materials were recovered from these zones. The underlying Zone 3 is a well-developed Ck horizon and is probably late Pleistocene in age. Three burned rock features were found, but none of them appeared intact. The chipped stone artifact density ranged from 5.7 to 145 items per cubic meter in the test units, with the average being 50.8 per cubic meter (see Table 4). Based on the testing results, 41SV153 is interpreted as a fairly low-density prehistoric campsite with no intact features, poor preservation of organic remains, and evidence of some reworking of the cultural deposits.

Bearing in mind that the tested portion of 41SV153 is only a small slice of what is probably a much larger site, the tested area has a low archeological research potential. Despite this, the site warrants some further discussion from a geoarcheological perspective, and two aspects of the site are given additional consideration here. First, one of the most notable aspects of 41SV153 is the prominent unconformity that represents a significant temporal gap in deposition as well as a major erosional episode. Other evidence suggests that this scouring, which is not dated at 41SV153 but probably occurred during the early to middle Holocene, may be represented in the alluvial stratigraphy at other locations upstream and downstream along the Brazos. If this widespread event is expressed at other archeological sites in the region, it has paleoclimatic implications for north-central Texas. Second, the cultural remains at 41SV153 are characterized as relatively low density and broadly dispersed, and archeological remains at other sites nearby are generally similar. Such low-density occupation debris appears to be typical of many sites throughout the region. Collectively, these sites hint at one particular facet of human land utilization patterns in this portion of north-central Texas.

\section{Geomorphology and Paleoclimatic Interpretation}

At 41SV153, the boundary between Zones 2 and 3 is an obvious geological unconformity (Figure 10). The Zone 3 deposit represents an older alluvium that was truncated by erosion, resulting in an undulating surface that was later covered with late Holocene alluvial deposits. Based on the site's alluvial stratigraphy and its topographic location relative to Squaw Creek and the Brazos River, it seems likely that the overlying late Holocene deposits (Zones 1 and 2) were laid down by Squaw Creek on top of a truncated Brazos River alluvial deposit (Zone 3).

A look at the geology and topography of the lower Squaw Creek valley supports these interpretations (Figures 11 and 12). The geological map shows that there are three distinct Quaternary surfaces within the hilly Cretaceous landscape. The highest surface is the $\mathrm{Qu}$, which is identified as "alluvium and Quaternary deposits undivided" and includes alluvial and colluvial fan deposits. In the vicinity of 41SV153, these deposits represent an ancient Pleistocene surface. The next surface is the Qt, a late Pleistocene alluvial terrace inset into the older $\mathrm{Qu}$ deposits. The lowest terrace is the Qal, which represents the Holocene deposits inset into the Qt terrace. It is likely that the ancient Brazos River is responsible for scouring out the broad valley at what is now the mouth of Squaw Creek, and at some point in the past the Brazos River probably looped northward (from the point where Squaw Creek and the Paluxy River converge) and abutted what is now the steep western edge of the Squaw Creek valley. The Brazos River deposited the sediments now recognized as $\mathrm{Qt}$ and $\mathrm{Qu}$ on the map. Inset into these older Brazos River deposits are the lower terrace (Qal) deposits of the Brazos River and Squaw Creek. The Holocene alluvium in Squaw Creek was deposited after the Brazos River became deeply incised and situated at or near its current channel configuration.

Given the geologic and topographic configuration of the valley, along with the stratigraphy exposed at 41SV153, a general sequence of depositional and erosional events is proposed for the site area as follows: 


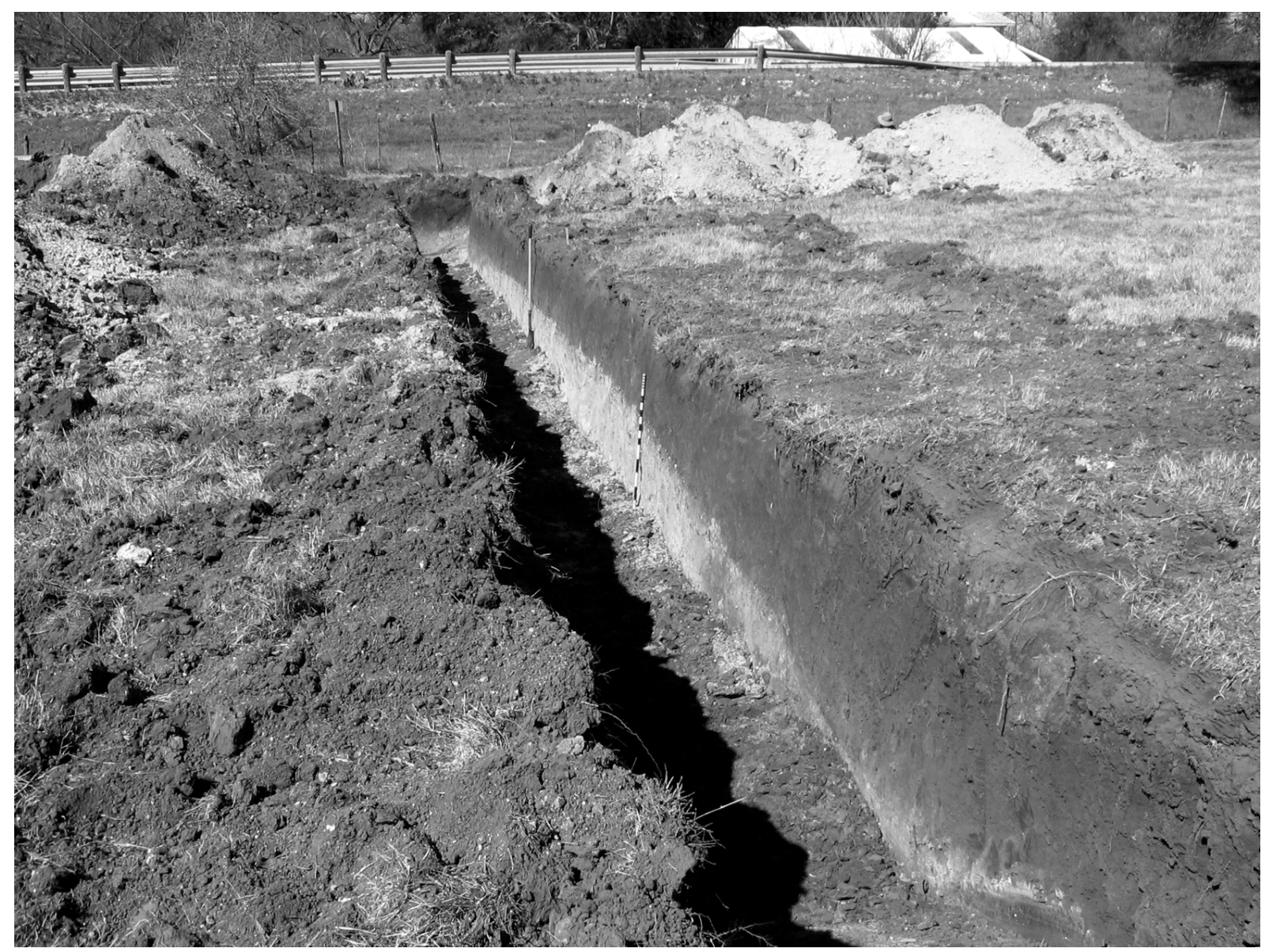

Figure 10. Photograph of alluvial sediments exposed in Backhoe Trench 8, looking westward to the point where the trench intersects Backhoe Trench 7. The abrupt and undulating contact between the overlying darker Zone 1 and 2 deposits and the light-colored Zone 3 deposit is a geological unconformity that represents a significant erosional episode.

DEPOSITION, PHASE I. The Brazos River deposited a sequence of alluvial and mixed alluvial/colluvial sediments (Pleistocene $\mathrm{Qt}$ and $\mathrm{Qu}$ ) in the site area. Subsequent pedogenesis probably resulted in the formation of a complete soil profile (A-B-Ck horizons) on the late Pleistocene terrace $(\mathrm{Qt})$. The location of the river channel at this time is not known, although modern aerial photographs hint at the presence of buried channel scars east of Squaw Creek.

EROSION EPISODE. Widespread erosional stripping of the Brazos River terrace occurred, effectively removing the $\mathrm{A}$ and $\mathrm{B}$ horizons and truncating the $\mathrm{Ck}$ horizon. It is likely that this erosion was caused by Squaw Creek, resulting in an exposed undulating surface.

DEPOSITION, PHASE II. After the scouring episode, Squaw Creek began to deposit fine-grained sediments resulting in alluvium (Qal) inset into the Pleistocene terrace and lapping on top of the older eroded surface. Pedogenic alteration occurred as these sediments aggraded, resulting in the formation of an A-B profile (Zones 1 and 2) resting unconformably on the ancient $\mathrm{Ck}$ horizon (Zone 3).

The cultural remains found in Backhoe Trenches 7 and 8 at 41SV153 are essentially buried within the lower terrace $(\mathrm{Qal})$ at the point where these sediments were deposited on top of 


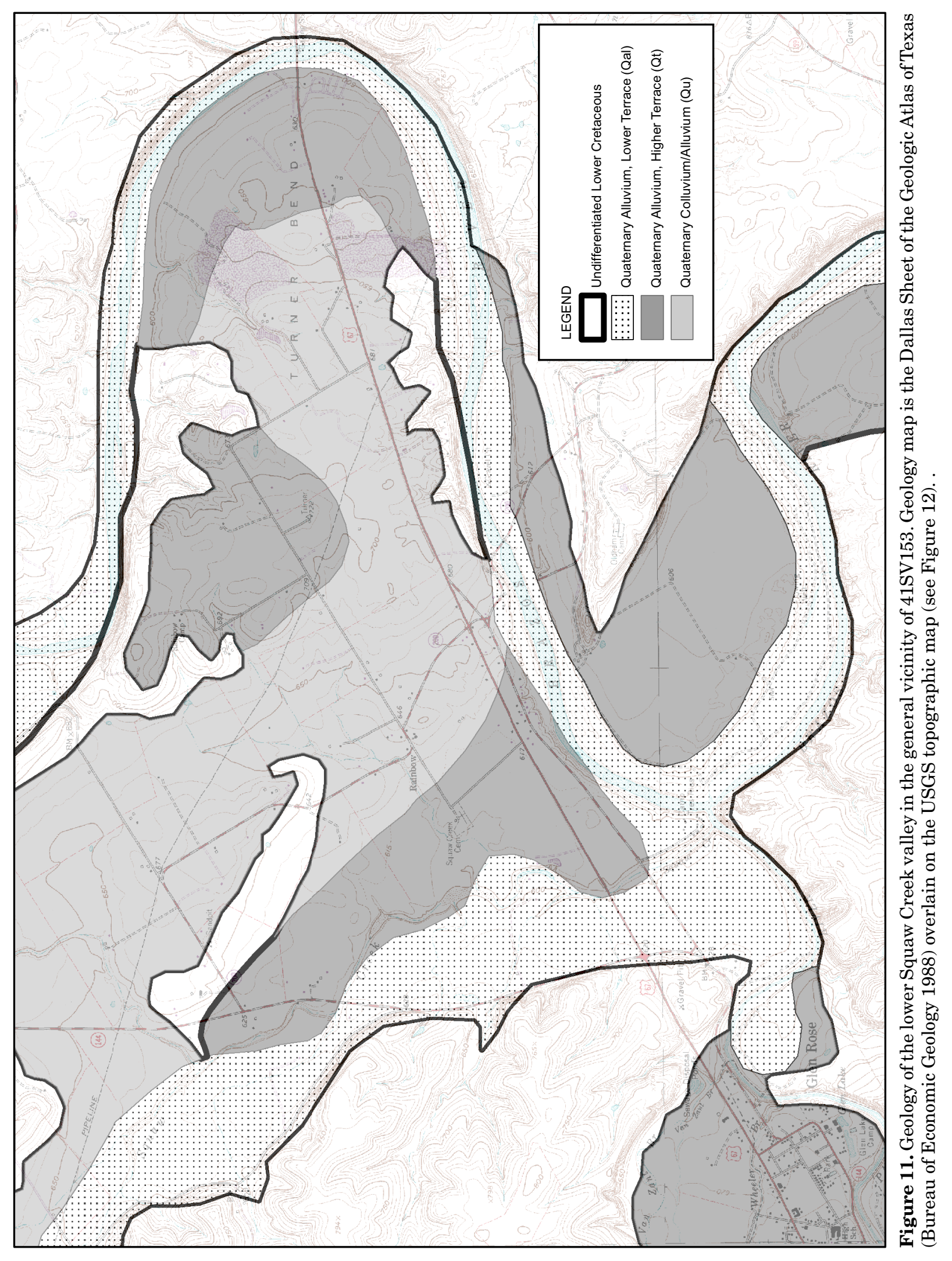




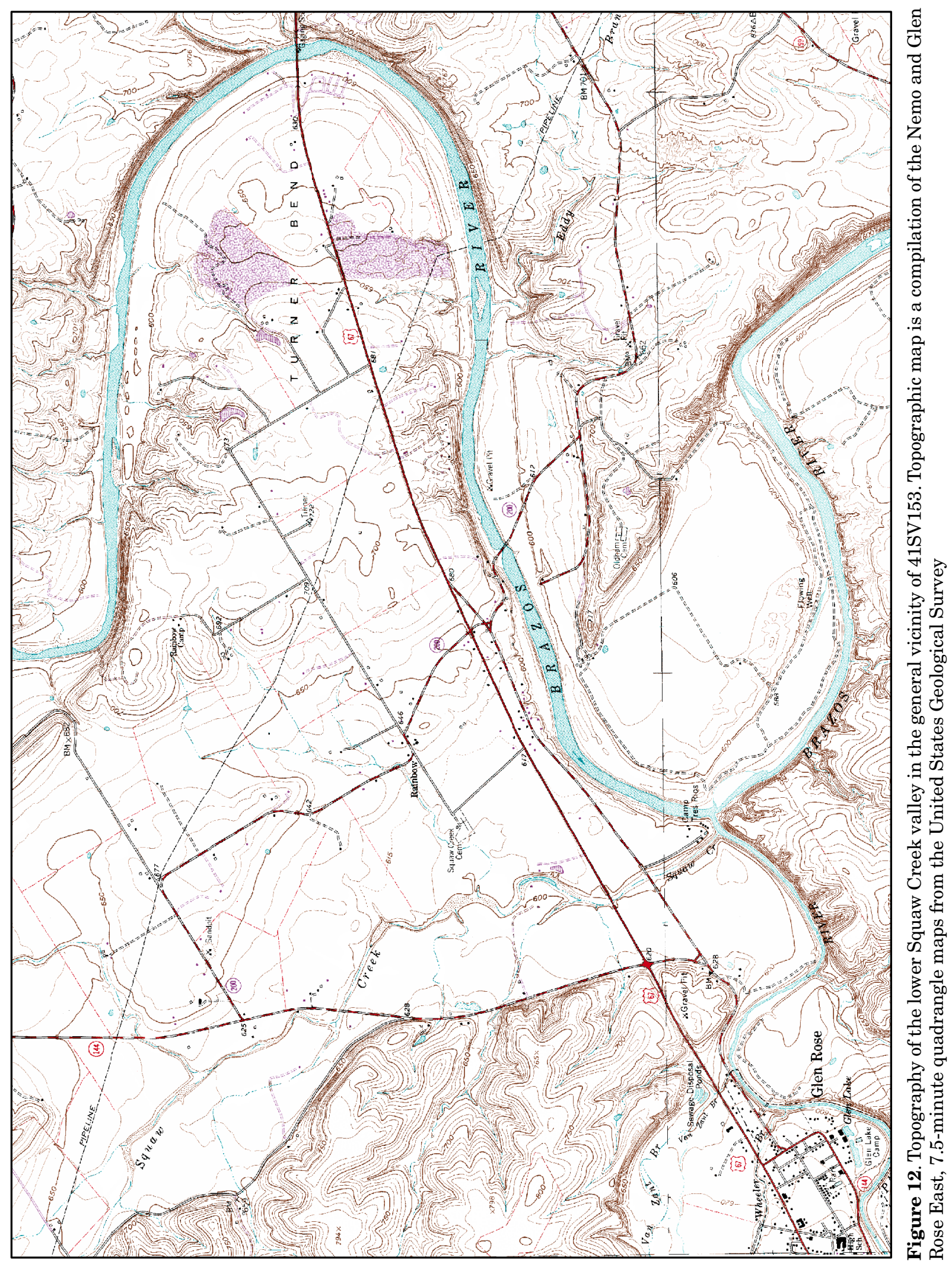


the eroded higher terrace deposits ( $\mathrm{Qt}$ ). Mechanical trenching shows that the late Holocene deposits are thickest near Squaw Creek (in Backhoe Trench 10) and become thinner moving away from the creek. Within this sequence of natural events proposed above, cultural occupations began at 41SV153 early in Phase II deposition. Cultural materials from these earliest human occupations were probably located on high spots on the eroded surface, but subsequent flooding appears to have disturbed these cultural materials. In some places, burned rocks and artifacts associated with these occupations have obviously been washed down and redeposited into depressions on the undulating surface. It appears that human activities at 41SV153 continued throughout the late Holocene, but the occupations were ephemeral and resulted in no significant accumulations of materials or features.

No organic samples were recovered for dating the cultural activities, and the precise ages of the important geomorphic events represented by these sediments cannot be determined. All of the Holocene sediments at 41SV153 appear to be less than ca. 2,000 to 5,000 years old based on the minimal degree of pedogenic alteration. No sediment sample was taken at the time of excavation, and in retrospect dating of soil humates from such a sample would have provided at least a gross minimal age for the onset of deposition of the overlying Holocene sediments. Waters (1992:79) argues that multiple samples from well-selected locations must be dated to establish the beginning and rate of deposition with any degree of accuracy. Defining the age and duration of the erosional event at 41SV153 is even more problematic. Waters (1992:79-83, Figure 78) presents a thorough discussion of the complexities of understanding degradational episodes that resulted in erosional surfaces. $\mathrm{He}$ stresses the need to determine two phenomena: the hiatus, or the duration (i.e., the beginning and ending time) of the erosional event, and the degradational vacuity, or the time represented by the missing sediments that were removed by the erosion at any given point. Degradational vacuity varies greatly from place to place, depending upon the severity of erosion and the degree of incising in each location. Consequently, it is hard to define the erosional episode in horizontally limited exposures with incomplete stratigraphic sequences (Waters 1992:83). The chronological problem at $41 \mathrm{SV} 153$ is compounded by the fact that soil humate dating of lower Zone 2 and upper Zone 3 sediments would provide an age estimate of the degradational vacuity (and this assumes that a humate date on the Zone 3 deposits would be reliable), but not the hiatus. From this discussion it may be concluded that to accurately define the chronology of deposition, degradation, and stability at 41SV153 and throughout Turner Bend would require more subsurface exposures and extensive chronometric sampling.

Despite the absence of any dated deposits at 41SV153, it seems likely that the erosional episode occurred sometime in the 5000 to 2000 B.P. range. The lack of organic enrichment and melanization of the Zone 3 sediments and the limited degree of pedogenic alteration of the Zone 1 and 2 sediments suggest that deposition of the overlying sediments began soon after the erosion event. If the general sequence of depositional and erosional events proposed above is generally correct, then the important question is: Do the geomorphic events inferred for 41SV153 represent a localized phenomenon, or do they correlate with broad patterns of erosion and deposition elsewhere in the Brazos River valley? Geomorphic data from three other locations in the Brazos River drainage help address this question (Figure 13).

In the late $1940 \mathrm{~s}$, archeological investigations were conducted at sites in Whitney Reservoir (now Lake Whitney), situated on the Brazos River $35 \mathrm{~km}$ (22 miles) downstream from 41SV153, (Stephenson 1947, 1970). Glen Evans and Theodore White made geological observations, and they noted that there were two alluvial terraces consistently present throughout this stretch of the central Brazos River valley. They identified an upper or " 40 -foot" terrace approximately $40 \mathrm{ft}$ above the channel and a lower or "20-foot" terrace approximately $20 \mathrm{ft}$ above the channel (Stephenson 1970:48-53). These terraces may generally equate with the Pleistocene ( $\mathrm{Qu}$ and $\mathrm{Qt})$ and Holocene (Qal) terrace surfaces at 41SV153. Perhaps more importantly, Stephenson (1970:53) noted that the terraces of the central Brazos River "... can be correlated especially well with those of the Colorado River. Terrace elevations are similar in the two stream valleys, and the composition of the alluvial fills in both are comparable in many respects." 


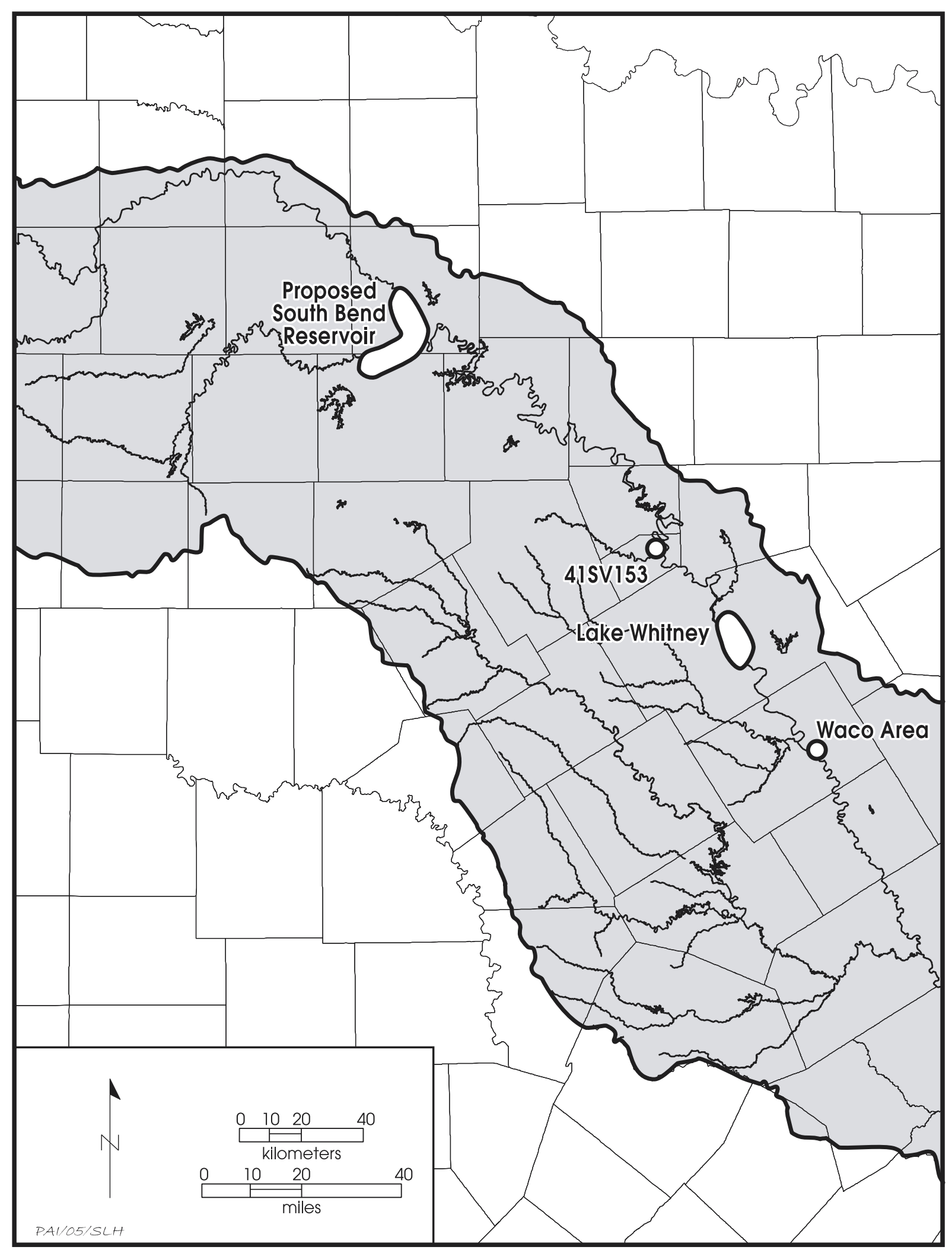

Figure 13. Map of the Brazos River valley in north-central Texas showing selected geoarcheological project locations. 
Lee Nordt (in Fields et al. 2000:77-79) conducted a geomorphic study of the Brazos River in the Waco area, about $100 \mathrm{~km}$ (62 miles) downstream from 41SV153. He defined a sequence of alluvial terrace deposits based on a series of soil humate dates from backhoe trenches on the southeast side of Waco. In this study, Backhoe Trench 2 was located on a Holocene terrace close to its interface with a higher Pleistocene terrace in a setting similar to that of 41SV153. A prominent geological unconformity was represented in the profile of this trench, and dates on the upper and lower deposits bracket the age of the erosional event between about $5260 \pm 40$ and $2000 \pm 60$ B.P. (Nordt 2000:Figure 5).

In conjunction with archeological studies at the South Bend Reservoir, Rolfe Mandel (1992) conducted geomorphic investigations at 10 locations along the Brazos River and Clear Fork of the Brazos River. He documented geological unconformities representing buried erosional surfaces in several locations that are about $130 \mathrm{~km}$ (80 miles) northwest of 41SV153. On a $\mathrm{T}_{2}$ of Fish Creek, a Brazos River tributary, a soil humate date of $5520 \pm 90$ B.P. was obtained on the underlying sediments (Mandel 1992:Figure 17). On Hubbard Creek, a tributary of the Clear Fork of the Brazos, a charcoal radiocarbon date places the age of the sediments below an erosional surface at ca. $4060 \pm 920$ B.P. (Mandel 1992:Figure 25). Humate radiocarbon dates also were obtained on sediments below erosional surfaces at two locations in the $\mathrm{T}_{1 \mathrm{~b}}$ of the Clear Fork; these dates were $7430 \pm 120$ B.P. and 4970 \pm 90 B.P. (Mandel 1992:Figure 25). Collectively, the data for the smaller stream valleys led Mandel (1992:81) to conclude that most of the $\mathrm{T}_{1}$ deposits accumulated between 4000 and 1000 B.P., and that the $\mathrm{T}_{2}$ settings are characterized by late Holocene sediments overlying eroded surfaces on older but undated deposits. The $\mathrm{T}_{1}$ deposits on the Brazos River are generally young, and Mandel (1992:81) notes that "aggradation appears to have been fairly rapid, thereby reducing the amount of time that the former floodplain surface would have been available for human occupation." For the $T_{1}$ terrace complex on the Clear Fork of the Brazos River, the upper deposits are of late Holocene age and are found, in many instances, lying on an older eroded surface. Mandel (1992:81) notes that the underlying "paleosols are truncated, with little or no portion of the A horizon remaining. Thus,
Early and Middle Archaic sites may have been stripped off former stable surfaces ...."

Collectively, the Waco area and South Bend Reservoir examples suggest that there was indeed a widespread erosional episode throughout the central and upper Brazos River drainage. The timing and duration of this erosion event(s) is poorly dated, but it probably occurred between 7,000 and 3,000 years ago. It also appears that similar geomorphic phenomenon are represented in the Colorado River drainage. Based on his intensive study of the lower Colorado River, Blum (1992:213-222, 230-231) proposed a paleoclimatic sequence that applies to the Edwards Plateau and south Texas. This sequence seems to generally agree with the sedimentation and erosion evidence for the Brazos River discussed above. Blum suggested that the climate was getting drier (a general decrease in effective moisture) from 10,500 to 5000 years B.P., and this culminated in the extremely dry conditions, essentially a prolonged drought, from 5,000 to 2,500 years ago. During this time, "the Edwards Plateau was covered by an open grassland and scrub vegetation, with rapidly disappearing soil and weathering profiles" (Blum 2992:218). This is a period when erosion may have been the dominant process at work, and this helps explain the skewed archeological record over much of Texas. Mandel (1992:82) notes that:

... all or most early- and middleHolocene alluvial deposits have been eroded from small valleys in the upper Brazos River drainage network. Alluvium of this age, however, is stored in alluvial fans and terrace fills in the large valleys. Buried paleosols are developed in early- and mid-Holocene valley fill, and have potential for containing Early and Middle Archaic sites, respectively. It is important to note, however, that most of the buried paleosols have been truncated by erosion; hence, archeological sites may have been stripped off old floodplain surfaces.

In terms of human occupation at 41SV153 and other sites in the Brazos River drainage, it is likely that extremely dry climatic conditions in the early to middle Holocene led to the widespread erosional episode evident in the Brazos 
River system. The timing of this episode coincides with the proposed Altithermal period that has been characterized by arid conditions, stream incision, and erosional stripping (e.g., Blum 1992:214-216; Mandel 1992:82; Nordt 1992:Figure 31). In addition, the interpretation that the Zone 1 and 2 sediments at 41 SV153 were deposited in the 5000 to 2000 B.P. range generally corresponds with a period of erosional stripping followed by alluviation seen in the Brazos, Colorado, and Concho River valleys (Blum and Valastro 1992:431, 434; Mandel 1992:78-79; Nordt 2000:77-79).

The erosional and depositional episodes represented at 41SV153, then, are related to regional paleoclimatic events proposed in various central Texas paleoenvironmental reconstructions by Johnson and Goode (1994:Figure 2), Nordt (1992:Figure 31), Nordt et al. (1994), and Collins (1995:Table 2). All of these reconstructions are based, at least in part, on regional geomorphic data from around central Texas. Kibler and Scott (2000:Figure 5) present graphic comparison of late Quaternary alluvial fills throughout the Balcones Canyonlands along the eastern and southern margins of the Edwards Plateau. Eight different geomorphic study areas, each with a fairly well-dated generalized stratigraphic sequence, are compared. All eight areas exhibit missing sediments denoting a major period of incision and erosion dating between 7,000 and 2,500 years ago. Seven of these localities suggest that the erosion episode and missing sediments date between 5,000 and 3,000 years ago, and alluvial deposition was the dominant process during the last 3,000 years. This evidence suggests that the erosional episode at 41SV153 occurred in connection with a widespread climatic pattern that affected all of central Texas.

\section{Low-density Sites and Prehistoric Land Use}

Despite the lack of chronological control at 41SV153, some attempt can be made to place the archeological remains into regional perspective. Site 41SV153 represents an open campsite characterized by low-density artifacts and dispersed or disturbed burned rock features with no preserved organic remains. The archeological remains from this testing are too sparse to make reliable chronological assignments or meaningful interpretations about human behavior. Recent archeological work in the Glen Rose area provides some comparative data on nearby sites and suggests that 41SV153 is not an anomaly. In 2004, archeological test excavations were done in a portion of 41SV4, and backhoe trenches and shovel tests were excavated in portions of 41SV51 and 41SV157 (Griffith 2004, 2005a). All of these sites contained low-density artifacts and generally amorphous burned rock features in Holocene alluvium, and the prehistoric cultural remains appear to be generally similar to those at 41SV153. Sites 41SV4 and 41SV51 are situated on the first terrace of Squaw Creek about $2 \mathrm{~km}$ south of 41SV153, and 41SV157 is situated on the first terrace of the Paluxy River about $4 \mathrm{~km}$ southwest of 41SV153.

Investigations at 41 SV51 were limited to three backhoe trenches that revealed very sparse cultural materials in the Holocene alluvial deposits (Griffith 2004). Similarly, investigations at 41SV157 were limited to three backhoe trenches and two shovel tests that resulted in documentation of light scatter of lithic debitage and small burned rocks within the late Holocene alluvium (Griffith 2005a). Because no features or organic remains were found in the deposits, no further work was warranted at either of these sites. Both of these sites are characterized as low-density sites where cultural remains are scarce enough that interpretation of the human activities represented is difficult.

Archeological testing of 41SV4 provides data that are more directly comparable to 41SV153, and the sites were investigated with a similar level of testing. A comparison of data for these two sites shows that they are similar in many ways (Table 5). Cultural materials at 41SV4 were found in the upper $100 \mathrm{~cm}$ of a dense clayey B horizon. Fine-grained sediments continued below this depth, but the cultural materials disappeared abruptly, with no evidence of an erosional unconformity as at 41SV153. Excavations at both sites produced similarly low artifact densities, although burned rock densities were considerably higher at 41SV4 than at 41SV153. Only one of the six burned rock features at 41SV4 was partially intact and yielded sparse charred plant remains.

It appears that several sites situated along major stream valleys in Somervell County exhibit similar patterns of low-density artifacts 
Table 5. Comparison of archeological data for 41SV4 and 41SV153 located on Holocene terraces of Squaw Creek

\begin{tabular}{|c|c|c|}
\hline & 41SV4 & 41SV153 \\
\hline Reference & Griffith (2004) & this report \\
\hline No. of backhoe trenches & 2 & 4 \\
\hline No. of test units & 7 & 17 \\
\hline Total area of test units & $7 \mathrm{~m}^{2}$ & $5.75 \mathrm{~m}^{2}$ \\
\hline Approximate size of intensive testing area & $15 \times 10 \mathrm{~m}$ & $35 \times 25 \mathrm{~m}$ \\
\hline Total area of intensive testing & $150 \mathrm{~m}^{2}$ & $875 \mathrm{~m}^{2}$ \\
\hline Volume of hand excavation & $4.35 \mathrm{~m}^{3}$ & $4.35 \mathrm{~m}^{3}$ \\
\hline $\begin{array}{l}\text { Total no. of chipped stone artifacts } \\
\text { (excludes flotation sample recovery) }\end{array}$ & 542 & 286 \\
\hline Range of artifact density per $\mathrm{m}^{3}$ & $9.4-202.5$ & $0.0-145.0$ \\
\hline Average artifact density per $\mathrm{m}^{3}$ & 124.6 & 65.5 \\
\hline No. of burned rock features recorded & 6 & 3 \\
\hline $\begin{array}{l}\text { Total weight of burned rocks } \\
\text { (feature and nonfeature contexts) }\end{array}$ & $1,484 \mathrm{~kg}$ & $178 \mathrm{~kg}$ \\
\hline Average burned rock density per $\mathrm{m}^{3}$ & $333.5 \mathrm{~kg}$ & $40.9 \mathrm{~kg}$ \\
\hline Temporally diagnostic specimens & Axtell point & $\begin{array}{l}\text { Darl point; } \\
\text { Hoxie point }\end{array}$ \\
\hline Charred organic remains recovered & $\begin{array}{c}\text { yes; small samples from } \\
\text { one feature }\end{array}$ & no \\
\hline
\end{tabular}

and scattered burned rocks, along with burned rock features that appear to be disturbed by natural processes. All of the sites mentioned above, including 41SV153, are in alluvial floodplain deposits along major streams or rivers. Gravel lenses or sandy deposits were recorded at each of these sites, interspersed with the finegrained alluvium. At 41SV153, for example, gravel lenses were present nearest the creek channel in the southern end of Backhoe Trench 7 and in Backhoe Trench 10. Such strata indicate that brief, high-energy flood episodes occurred at all of these sites. These types of flood events undoubtedly affected the integrity of the cultural remains that were on the surface at the time, and they may account, at least in part, for the apparent disturbed nature of most of the burned rock features and the near-absence of associated charred remains. In addition, the fact that these alluvial settings were subject to occasional high-energy flooding means that conditions were not conducive to long-term and intensive occupation as might be expected at larger residential base camps. In conclusion, it is likely that low-density artifact sites such as 41SV4 and 41SV153 do represent low-intensity human use and reflect something about how prehistoric peoples lived, regardless of the fact that these kinds of sites are inherently hard to interpret.

\section{SITE EVALUATION AND RECOMMENDATIONS}

Investigation of 41SV153 yielded limited stone artifacts and three amorphous burned rock features, but no associated organic remains were found. Though part of 41SV153 appears to represent repeated prehistoric occupations buried in Holocene alluvium, the artifacts and features are so sparse that they are difficult to interpret. The paucity of temporally diagnostic artifacts and the lack of organic remains suggest that establishing the chronology of the cultural occupations would be difficult. Furthermore, the three burned rock features encountered do not appear to represent intact primary activity locations. Rather, the patterning of the burned rocks suggests that they were disturbed by natural processes (such as flooding) or continued cultural activities (later occupations disturbing earlier deposits). Consequently, the site lacks the capacity to contribute important information, and it is recommended that 
the portion of $41 \mathrm{SV} 153$ within the current project area is not eligible for listing in the National Register of Historic Places or designation as a State Archeological Landmark. No further work is recommended for the portion of $41 \mathrm{SV} 153$ within the proposed construction easement.

\section{GENERAL RECOMMENDATIONS}

In this final section, we present concluding thoughts on what the two interpretations offered earlier for 41SV153 might mean for future archeological research in north-central Texas. The two interpretations are that: (1) 41SV153 is a low-density site that typifies many such sites in the vicinity; and (2) the well-defined erosional surface at 41SV153 corresponds with other regional evidence of significant paleoclimatic events and widespread erosion during the middle Holocene.

Many prehistoric archeological sites in alluvial settings may be characterized as having a fairly low density of artifacts, sparse features that are seldom intact, and poor preservation of organic remains. These sites are both frustrating and puzzling. Recent investigations for TxDOT road projects in Somervell County have identified four such sites-41SV4, 41SV151, 41SV153, and 41SV157-(Griffith 2004; Griffith 2005a; this report). Portions of these sites were discovered and tested as required by federal and state cultural resources laws, but each of these sites was found to have a low archeological research potential, or the testing exhausted the archeological potential of the sample area. The portions of these sites within the project area were considered ineligible for listing in the National Register or designation as State Archeological Landmarks, and it was recommended that the road projects be given clearance to proceed. Yet, in each case the question of whether we are missing something important by not looking harder at these low-density sites was asked. The investigated portions of these sites are, admittedly, only small samples of much larger sites, and it is possible that they represent low-density areas on the margins of larger sites where cultural activities were more intensive. It is equally likely, however, that these tested areas are representative of the larger sites they are parts of. It is likely that many sites in alluvial settings that have low artifact densities and dispersed features do reflect the behavioral choices of prehistoric huntergatherer peoples. In contrast with large residential base camps that were intensively occupied (i.e., display abundant artifacts, intact features, and organic remains in stratified contexts), these low-density alluvial sites appear to represent a different type of human behavior. Within a broad theoretical framework of understanding how prehistoric hunter-gatherers used the landscape through time, these ephemeral sites should tell an important part of the story, and we know that they must represent some type of adaptation that may not be duplicated in any other archeological setting. Unfortunately, however, these kinds of sites are not contributing much to our understanding of human prehistory.

When we find sites such as these, they are expensive and time consuming to investigate. When the information returned from testing is low, these sites are dropped from consideration for further work. We have not learned how to investigate such sites cost effectively and in ways that will produce meaningful results. This is not a criticism of archeologists or the state of archeological research in Texas. Rather, this statement simply reflects the realistic limitations imposed by currently available archeological field methods and analytical techniques. We do not propose any solutions to dealing with these problematic low-density prehistoric sites but suggest that continuing the debate on this topic is important.

Returning to the second interpretation, the erosional unconformity evident at 41SV153 reflects broader paleoclimatic and geomorphic patterns that we seek to understand. Michael Waters (1992:183) summarized the importance of understanding human adaptations to dynamic alluvial landscapes in his book, Principles of Geoarchaeology:

Alluvial environments are dynamic and constantly changing. Because of this, the archaeological record contained within them is severely fragmented. This concept is important to consider for the proper interpretation of a site or a regional settlement system. Reconstructing alluvial landscapes is also important because there is a direct relationship between alluvial landscapes and human 
activity. The choice of settlement location and changes in activity and settlement loci are strongly influenced by changes in the landscape....

Given this perspective, it seems that some TxDOT projects may present unique opportunities for gathering nonsite geomorphic data that are useful for regional paleoclimatic reconstruction and building models of landscape evolution. These data also are important for understanding the archeological sites that are found. The proposed improvements to the SH 144 bridge at Squaw Creek and the SH 67 bridge at Squaw Creek are good examples. Although the cultural resources work focused on identifying and evaluating the archeological sites (i.e., 41SV4, 41SV51, and 41SV153; see
Griffith [2004, 2005a]; this report) at these stream crossings, having a broader geomorphic perspective is important and would be helpful in fully understanding these localities. It is notable that these roads crosscut all of the lower end of the Squaw Creek valley from north to south and all of Turner Bend, a prominent Brazos River meander, from east to west. One could argue that a geomorphic study involving core sampling and correlating alluvial profiles all along the roads (within existing rights of way) across the Squaw Creek and Brazos River valleys should be done before the archeological site testing. Such a study would be justifiable because it would yield important data to help reconstruct the alluvial landscapes of the past and provide a framework for interpreting the human occupations on those landscapes. 


\section{REFERENCES CITED}

Binford, Lewis R.

1980 Willow Smoke and Dogs' Tails: HunterGatherer Settlement Systems and Archaeological Site Formation. American Antiquity 45(1):4-20.

Black, Stephen L., and A. Joachim Mc Graw 1985 The Panther Springs Creek Site: Cultural Change and Continuity within the Upper Salado Creek Watershed, South-Central Texas. Archeological Survey Report No. 100. Center for Archaeological Research, The University of Texas at San Antonio.

Black, Stephen L., Linda W. Ellis, Darrell G. Creel, and Glenn T. Goode

1997 Hot Rock Cooking on the Greater Edwards Plateau: Four Burned Rock Midden Sites in West Central Texas, Volumes 1 and 2. Studies in Archeology 22. Texas Archeological Research Laboratory, The University of Texas at Austin. Archeology Studies Program, Report 2. Environmental Affairs Department, Texas Department of Transportation, Austin.

Bolton, Herbert E.

1970 Texas in the Middle Eighteenth Century: Studies in Spanish Colonial History and Administration. The Texas State Historical Association and the University of Texas Press, Austin.

Bousman, C. Britt

1998 Paleoenvironmental Change in Central Texas: The Palynological Evidence. Plains Anthropologist 43(164):201-219.

Bureau of Economic Geology

1988 The Geologic Atlas of Texas, Dallas Sheet. Bureau of Economic Geology, The University of Texas at Austin.

Campbell, Thomas N.

1988 Indians of Southern Texas and Northeastern Mexico: Selected Writings of Thomas Nolan Campbell. Texas Archeological Research Laboratory, with the cooperation of the Department of Anthropology, the College of Liberal Arts, and the Institute of Latin American Studies, The University of
Texas at Austin.

Castañeda, Carlos E.

1936- Our Catholic Heritage in Texas, 1519-1936.

19567 vols. Von Boeckmann-Jones Co., Austin.

Coburn, Winifred C.

1978 Soil Survey of Hood and Somervell Counties, Texas. United States Department of Agriculture, Soil Conservation Service, in cooperation with the Texas Agricultural Experiment Station.

Collins, Michael B.

1968 A Note on Broad Corner-Notched Projectile Points Used in Bison Hunting in Western Texas. The Bull Roarer 3(2):1314. The University of Texas Anthropological Society, Department of Anthropology, The University of Texas at Austin.

1990 The Archaeological Sequence at Kincaid Rockshelter, Uvalde County, Texas. Transactions of the Twenty-Fifth Regional Archeological Symposium for Southeastern New Mexico and Western Texas, pp. 25-34.

1995 Forty Years of Archeology in Central Texas. Bulletin of the Texas Archeological Society 66:361-400.

Collins, Michael B., Bruce Ellis, and Cathy Dodt-Ellis 1990 Excavations at the Camp Pearl Wheat Site (41KR243): An Early Archaic Campsite on Town Creek, Kerr County, Texas. Studies in Archeology 6. Texas Archeological Research Laboratory, The University of Texas at Austin.

Dering, Phil

1999 Earth-Oven Plant Processing in Archaic Period Economies: An Example from a Semi-arid Savannah in South-Central North America. American Antiquity 64(4):659-674.

Dial, Susan, Anne C. Kerr, and Michael B. Collins 1998 Projectile Points. In Wilson-Leonard: An 11,000-year Archeological Record of 
Hunter-Gathers in Central Texas, assembled and edited by Michael B. Collins, pp. 313-444. Studies in Archeology 31. Texas Archeological Research Laboratory, The University of Texas at Austin. Archeological Studies Program, Report 10. Environmental Affairs Division, Texas Department of Transportation, Austin.

Dibble, David S., and Dessamae Lorrain

1968 Bonfire Shelter: A Stratified Bison Kill Site, Val Verde County, Texas. Miscellaneous Papers No. 1. Texas Memorial Museum, The University of Texas at Austin.

Fields, Ross C., E. Frances Gadus, Karl W. Kibler, and Lee C. Nordt

2000 Archeological Impact Evaluations and Surveys in the Texas Department of Transportation's Atlanta, Dallas, Fort Worth, Paris, and Waco Districts, 19982000. Reports of Investigations No. 128. Prewitt and Associates, Inc., Austin. Archeological Studies Program Report, No. 24. Environmental Affairs Division, Texas Department of Transportation, Austin.

Fox, Daniel E.

1979 The Lithic Artifacts of Indians at the Spanish Colonial Missions, San Antonio, Texas. Special Report No. 8. Center for Archaeological Research, The University of Texas at San Antonio.

Gibbs, Tim

2004 Archeological Survey on SH 144 at Squaw Creek, Somervell County, Texas. Letter Report No. 670. Prewitt and Associates, Inc., Austin.

Goode, Glenn T.

1991 Late Prehistoric Burned Rock Middens in Central Texas. In The Burned Rock Middens of Texas: An Archeological Symposium, edited by Thomas R. Hester, pp. 71-93. Studies in Archeology 13. Texas Archeological Research Laboratory, The University of Texas at Austin.

Griffith, Timothy B.

2004 Archeological Survey on U.S. Highway 67 at Squaw Creek, Somervell County, Texas. Letter Report No. 686. Prewitt and Associates, Inc., Austin.

2005a Archeological Survey on U. S. Highway 67 at the Paluxy River, Somervell County, Texas. Letter Report No. 706. Prewitt and Associates, Inc., Austin. 2005b Interim Report on Test Excavations at 41SV153, Somervell County, Texas. Manuscript submitted to the Environmental Affairs Division, Texas Department of Transportation, Austin, March 2005.

Hester, Thomas R.

1989 Historic Native American Populations. In From the Gulf to the Rio Grande: Human Adaptation in Central, South, and Lower Pecos, Texas, by Thomas R. Hester, Stephen L. Black, D. Gentry Steele, Ben W. Olive, Anne A. Fox, Karl J. Reinhard, and Leland C. Bement, pp. 77-84. Research Series No. 33. Arkansas Archeological Survey, Fayetteville.

Huebner, Jeffrey A.

1991 Late Prehistoric Bison Populations in Central and South Texas. Plains Anthropologist 36(137):343-358.

Jelks, Edward B.

1962 The Kyle Site: A Stratified Central Texas Aspect Site in Hill County, Texas. Archaeology Series No. 5. Department of Anthropology, The University of Texas at Austin.

Johnson, Leroy Jr.

1995 Past Cultures and Climates at Jonas Terrace: 41ME29 of Medina County, Texas. Report No. 40. Office of the State Archeologist, Texas Historical Commission, Austin.

Johnson, LeRoy Jr., and Glenn T. Goode

1994 A New Try at Dating and Characterizing Holocene Climates, as Well as Archeological Periods, on the Eastern Edwards Plateau. Bulletin of the Texas Archeological Society 65:1-51.

Johnson, Leroy Jr., Dee Ann Suhm, and Curtis D. Tunnell

1962 Salvage Archeology of Canyon Reservoir: The Wunderlich, Footbridge, and Oblate Sites. Bulletin No. 5. Texas Memorial Museum, The University of Texas at Austin.

Kelley, J. Charles, Thomas N. Campbell, and Donald J. Lehmer

1940 The Association of the Archeological Materials with Geological Deposits in the Big Bend Region of Texas. Bulletin 8. Sul Ross State Teachers College, Alpine.

Kibler, Karl W., and Ann M. Scott

2000 Archaic Hunters and Gatherers of the 
Balcones Canyonlands: Data Recovery Excavations at the Cibolo Crossing Site (41BX377), Camp Bullis Military Reservation, Bexar County, Texas. Reports of Investigations No. 126. Prewitt and Associates, Inc., Austin.

Kleinbach, Karl, Gemma Mehalchick, James T. Abbott, and J. Michael Quigg

1995 Other Analyses. In NRHP Significance Testing Of 57 Prehistoric Archeological Sites On Fort Hood, Texas, Volume II, edited by James T. Abbott and W. Nicholas Trierweiler, pp. 765-842. Archeological Resource Management Series, Research Report No. 34. United States Army, Fort Hood.

Mandel, Rolfe D.

1992 Geomorphology. In An Archeological Survey of the Proposed South Bend Reservoir Area: Young, Stephens, and Throckmorton Counties, Texas, by Joe W. Saunders, C. S. Mueller-Wille, and David L. Carlson, pp. 53-84. Archeological Surveys No. 6 . Archeological Research Laboratory, Texas A\&M University, College Station.

McKinney, Wilson W.

1981 Early Holocene Adaptations in Central and Southwestern Texas: The Problem of the Paleoindian-Archaic Transition. Bulletin of the Texas Archeology Society 52:91-120.

Newcomb, W. W., Jr.

1961 The Indians of Texas. University of Texas Press, Austin.

Nordt, Lee C.

1992 Archaeological Geology of the Fort Hood Military Reservation, Fort Hood, Texas. Research Report No. 25, Archaeological Resource Management Series. United States Army, Fort Hood.

Nordt, Lee C., Thomas W. Boutton, Charles T. Hallmark, and Michael R. Waters

1994 Late Quaternary Vegetation Changes in Central Texas Based on the Isotopic Composition of Organic Carbon. Quaternary Research 41:109-120.

Prewitt, Elton R.

1966 Preliminary Report on the Devil's Rockshelter. Texas Journal of Science 18(2):206-224

1981 Cultural Chronology in Central Texas.
Bulletin of the Texas Archeological Society 52:65-89.

1985 From Circleville to Toyah: Comments on Central Texas Chronology. Bulletin of the Texas Archeological Society 54:201-238.

Skinner, S. Alan, and Joseph Gallagher

1974 An Evaluation of the Archaeological Resources at Lake Whitney, Texas. Contributions in Anthropology No. 14. Institute for the Study of Earth and Man, Department of Anthropology, Southern Methodist University, Dallas.

Sorrow, William M.

1969 Archeological Investigations at the John Ischy Site: A Burned Rock Midden in Williamson County, Texas. Papers of the Texas Archeological Salvage Project No. 18. The University of Texas at Austin.

Stephenson, Robert L.

1947 Archaeological Survey of Whitney Basin: A Preliminary Report. Bulletin of the Texas Archeological Society 18:129-142.

1970 Archeological Investigations in the Whitney Reservoir Area, Central Texas. Bulletin of the Texas Archeological Society 41:37-286.

Story, Dee Ann

1985 Adaptive Strategies of Archaic Cultures of the West Gulf Coastal Plain. In Prehistoric Food Production in North America, edited by R. I. Ford, pp. 19-56. Anthropological Papers 75. Museum of Anthropology, University of Michigan, Ann Arbor.

Thoms, Alston V., and Rolfe D. Mandel

1991 The Richard Beene Site: A Deeply Stratified Paleoindian to Late Prehistoric Occupation in South-Central Texas. Current Research in the Pleistocene 9:42-44.

Toomey, Rickard S. III, Michael D. Blum, and Salvatore Valastro Jr.

1993 Late Quaternary Climates and Environments of the Edwards Plateau, Texas. Global and Planetary Change 7:299-320.

Weir, Frank A

1976 The Central Texas Archaic. Ph.D. dissertation, Department of Anthropology, Washington State University, Pullman.

Wandsnider, L.

1997 The Roasted and the Boiled: Food 
Composition and Heat Treatment with Special Emphasis on Pit-Hearth Cooking. Journal of Anthropological Archaeology 16:1-48.

Waters, Michael R.

1992 Principles of Geoarchaeology: A North American Perspective. University of Arizona Press, Tucson.

Wesolowsky, Al B., Thomas R. Hester, and Douglas R. Brown

1976 Archeological Investigations at the Jetta
Court Site (41TV151) Travis County, Texas. Bulletin of the Texas Archeological Society 47:25-87.

Willey, Gordon R., and Phillip Phillips 1958 Method and Theory in American Archaeology. University of Chicago Press, Chicago.

Wilson, Ernest W.

1930 Burnt Rock Mounds of Southwest Texas. Bulletin of the Texas Archaeological and Paleontological Society 2:59-63. 